\title{
LETRAMENTO LITERÁRIO, AMPLIAÇÃO DE REPERTÓRIO E ADAPTAÇÃO: INTER-RELAÇÕES ENTRE O CONTO, O CINEMA E OS "CAUSOS" POPULARES
}

\author{
EDUARDO NOGUEIRA
}

Prof. Dr. Marco Aurélio de Sousa Mendes 
Nogueira, Eduardo.

Letramento Literário, Ampliação de Repertório e Adaptação : inter-relaçōes entre o conto, o cinema e os "causos" populares / Eduardo Nogueira. - 2021.

$104 \mathrm{f}$.

Orientador: Marco Aurélio de Sousa Mendes

Dissertação (mestrado profissional) - Universidade Federal de Juiz de Fora, Faculdade de Letras. Programa de Pós-Graduação em Letras, 2021.

1. Letramento Literário. 2. Ampliação de Repertório. 3. "Causos" populares. 4. Adaptação . 5. Conto. I. Mendes, Marco Aurélio de Sousa, orient. II. Título. 


\title{
Ficha técnica
}

Organizadores

\author{
Elza de Sá Nogueira \\ Érika Kelmer Mathias \\ Luciana Teixeira \\ Marco Aurélio de Sousa Mendes \\ Natália Sathler Sigiliano \\ Patrícia Pedrosa Botelho \\ Thais Fernandes Sampaio
}

Universidade Federal de Juiz de Fora

Mestrado Profissional em Letras

2021 


\title{
Apresentação da Coleção de Cadernos Pedagógicos PROFLETRAS/UFJF 2021
}

\author{
Érika Kelmer Mathias \\ Natália Sathler Sigiliano
}

O mestrado profissional em Letras da Universidade Federal de Juiz de Fora tem assumido, desde a sua constituição, em 2013, o compromisso de um trabalho desenvolvido em prol da capacitação de professores de Língua Portuguesa da rede básica de ensino fundamental, o que tem contribuído para a melhoria da qualidade de ensino da região e do país.

Como uma maneira de formar professores em seu próprio campo de atuação, assim como de impactar professores fora do programa - a quem seja possível o acesso ao conhecimento das práticas de pesquisas realizadas -, a elaboração de produtos educacionais de ensino é inserida como requisito básico da formação dos professores que ingressam nesse mestrado. Desde 2013, esse trabalho esteve integrado à realização de uma prática pedagógica interventiva inserida no contexto de sala de aula em que o professor, agora também pesquisador, atuava.

No ano de 2020, um cenário educacional atípico se revelou em todo o Brasil e no mundo - devido à pandemia provocada pelo novo coronavírus. Nesse ano, diversos alunos da Turma 6 do PROFLETRAS da UFJF já haviam iniciado, em fevereiro de 2020, a aplicação de suas propostas de intervenção em salas de aula presenciais, e outros tinham planos de fazê-lo ainda nos primeiros meses do mesmo ano. No entanto, como forma de assegurar a saúde dos diversos atores envolvidos na esfera escolar, as aulas presenciais precisaram ser subitamente interrompidas, no país, ao longo do mês de março de 2020. Diante dessa realidade, enquanto as redes privadas puderam rapidamente adotar ações no sentido de implementar um ensino remoto emergencial, adquirindo dispositivos, softwares e programas específicos, as redes públicas só conseguiram iniciar as atividades remotas meses depois do início da suspensão das aulas presenciais. Em alguns estados e municípios, o ensino remoto emergencial só se iniciou no segundo semestre de 2020. Nesse sentido, o impacto nas pesquisas em curso no programa foi muito forte, não somente em função do intervalo de contato entre o professor-pesquisador e sua turma de atuação, como, 
principalmente, diante do novo cenário com o ensino remoto, cujas ações foram aplicadas de formas diferentes por estados e municípios: aulas remotas síncronas através de plataformas e/ou aplicativos de mensagens; aulas remotas assíncronas através de plataformas, TVs, material impresso e entregue aos alunos; materiais didáticos organizados pelas redes de ensino, sem a participação do professor; materiais criados e/ou adaptados pelos professores em seus anos e turmas de atuação; além de outras modalidades.

Dessa maneira, sensível a esse contexto, a coordenação nacional do mestrado profissional em Letras, por meio da resolução nº 003/2020, em 02 de junho de 2020, autorizou, de forma inédita, a possibilidade de serem realizadas, no âmbito do programa, propostas de ensino que não necessariamente tivessem caráter interventivo.

Diante disso, a Turma 6 do PROFLETRAS da UFJF colocou-se o desafio de realizar - ou de continuar a realizar - pesquisas as quais, mesmo em um contexto de muita apreensão e angústia quanto à vida e ao trabalho, resultaram em um conjunto de Cadernos Pedagógicos que apresentam características diversificadas quanto à situação de elaboração: alguns deles foram aplicados, mesmo em meio a um cenário atípico de aulas remotas; outros se compuseram de propostas de ações e atividades cujas aplicações poderão ser desenvolvidas futuramente.

É importante destacar também que, assim como todo texto que se constrói em interação com seus leitores, a constituição desses produtos pedagógicos contou - e contará - com uma rede de colaboração de diversos atores: professores e orientadores do programa, professores-discentes do mestrado profissional, professores participantes de bancas de qualificação e defesa, professores-colegas dos discentes do programa, alunos da rede básica que se propuseram a fazer parte das pesquisas e, ainda, professores que poderão conhecer, analisar, modificar e empregar estratégias inspiradas, em alguma medida, por aquelas aqui apresentadas por meio desta coleção.

Todos os Cadernos Pedagógicos tiveram como escopo a ideia de que "a especificidade da formação pedagógica, tanto a inicial como a contínua, não é refletir sobre o que se vai fazer, nem sobre o que se deve fazer, mas sobre o que se faz" (HOUSSAYE, 1995, p.28), no desejo de que esse pensamento guie não somente os autores, mas também os futuros leitores desses Cadernos a reflexões e ações sobre seus próprios fazeres pedagógicos. 
É nessa esteira que, mais uma vez, apesar de todos os percalços do momento atual na educação, os Cadernos Pedagógicos produzidos no âmbito do PROFLETRAS/UFJF trazem propostas autorais e inovadoras de ensino de Língua Portuguesa e Literatura, revelando forte compromisso por parte dos professores envolvidos em sua produção com o ensino público de qualidade. 


\section{Apresentação do projeto}

Caro professor,

É com muita satisfação, carinho e dedicação que apresentamos a você uma proposta pedagógica que contempla o letramento literário e a ampliação de repertório a ser aplicado numa classe de $9^{\circ}$. ano do ensino fundamental. $O$ ensino de língua portuguesa, além das competências e habilidades que se referem aos conteúdos gramaticais necessários aos estudantes, deve também abrir espaço para o universo da palavra literária, que permite brincar, sonhar, fabular, criar e recriar, inventar e reinventar, contar e recontar. É nesse sentido que esta proposta foi elaborada: contribuir para trazer o repertório dos causos populares da comunidade onde os estudantes estão inseridos para a sala de aula, e transformá-lo de modo sistematizado em contos.

É muito importante a escola abrir suas portas para os saberes que os alunos já trazem de sua vivência. Nós - professores de língua portuguesa - sabemos que os nossos discentes chegam a nossas aulas demonstrando possuir um amplo conhecimento interno da língua, utilizando e recriando as palavras em diversos contextos de uso. Cabe aos professores de língua portuguesa mostrar a eles que todas as variações linguísticas devem ser respeitadas, valorizadas, mas em seu lugar adequado de uso. É preciso, também, ensinar a eles que todos esses modos de conceber a linguagem e de interagir com a própria língua é o que a torna única e rica em sentidos.

Por essa razão é que, com esta modesta sequência interventiva, que lhes apresentamos, concretizamos a proposta de se realizar um novo modo de trabalhar, apresentando contos, que fazem parte do repertório universal e até mesmo da cultura popular, explicando aos estudantes como esses textos, muitos oriundos da tradição oral, são reconstruídos em modelos de registros escritos e até mesmo em outras formas de mídia como, por exemplo, em adaptações realizadas em obras cinematográficas.

Ademais, para que essa proposta se desenvolva satisfatoriamente, além da exploração dos contos e das adaptações filmicas, tomamos como base de conteúdo o conceito de conto, suas características, a estrutura e uma breve noção das categorias 
da narrativa, além do conceito e de algumas características das adaptações, a fim de possibilitar aos estudantes a construção do letramento literário e a ampliação de seu repertório.

Como forma de examinar o progresso dos discentes em relação à construção do próprio letramento literário e da ampliação de repertório, ao final da sequência pedagógica, propomos uma atividade de produção textual. Com essa atividade, conforme mostrado adiante, visamos valorizar as histórias populares presentes no contexto de vida dos discentes e incentivar que eles as registrem no formato do gênero textual conto.

Para saber mais sobre os conteúdos teóricos que embasaram a prática dessa intervenção pedagógica, convidamos todos vocês interessados por essa temática a lerem a dissertação que acompanha o presente caderno pedagógico. Acreditamos que os conteúdos apresentados poderão agregar bastante conhecimento ao de vocês.

Esperamos que nossos professores/leitores não somente apreciem conhecer e utilizar este material, mas que ele possa ser utilizado, reutilizado, recriado, reinventado pelos seus saberes e pelas suas mãos professorais, conhecedoras da realidade de sua sala de aula e das histórias que nela se manifestam...

Sejam muito bem-vindos!

Clique aqui para baixar a dissertação. 


\section{Sumário}

Motivação: Da tradição oral à compilação 10

$\begin{array}{ll}1^{\circ} \text { Momento } & 10\end{array}$

$\mathbf{2}^{\circ}$ Momento 12

Etapa 1: Do acervo popular à adaptação 16

$1^{\circ}$ Momento 16

$2^{\circ}$ Momento 20

$3^{\circ}$ Momento 21

$4^{\circ}$ Momento 23

$5^{\circ}$ Momento 26

Etapa 2: Do "causo" à adaptação 30

$1^{\circ}$ Momento 30

Etapa 3: Uma adaptação filmica

$\begin{array}{ll}1^{\circ} \text { Momento } & 35\end{array}$

$\begin{array}{ll}2^{\circ} \text { Momento } & 37\end{array}$

$3^{\circ}$ Momento 38

Etapa 4: Da adaptação ao texto original 40

$1^{\circ}$ Momento 40

Etapa 5: Atividade Avaliativa - "Quem conta um conto aumenta um ponto" 45

$1^{\circ}$ Momento 45

$2^{\circ}$ Momento 46

$3^{\circ}$ Momento $\quad 48$

$\begin{array}{ll}4^{\circ} \text { Momento } & 50\end{array}$

6- Referências Bibliográficas

Anexos $\quad 53$ 


\section{Motivação: Da tradição oral à compilação}

Tempo: 4 aulas/50 min

Esta etapa de motivação visa suscitar a curiosidade dos alunos em relação aos contos que se originam na tradição oral a partir da exploração de imagens e da leitura de um conto com duas versões.

\section{$1^{\circ}$ Momento}

- Com o objetivo de mostrar que os contos se originam da tradição oral, o professor projetará a seguinte imagem no quadro.

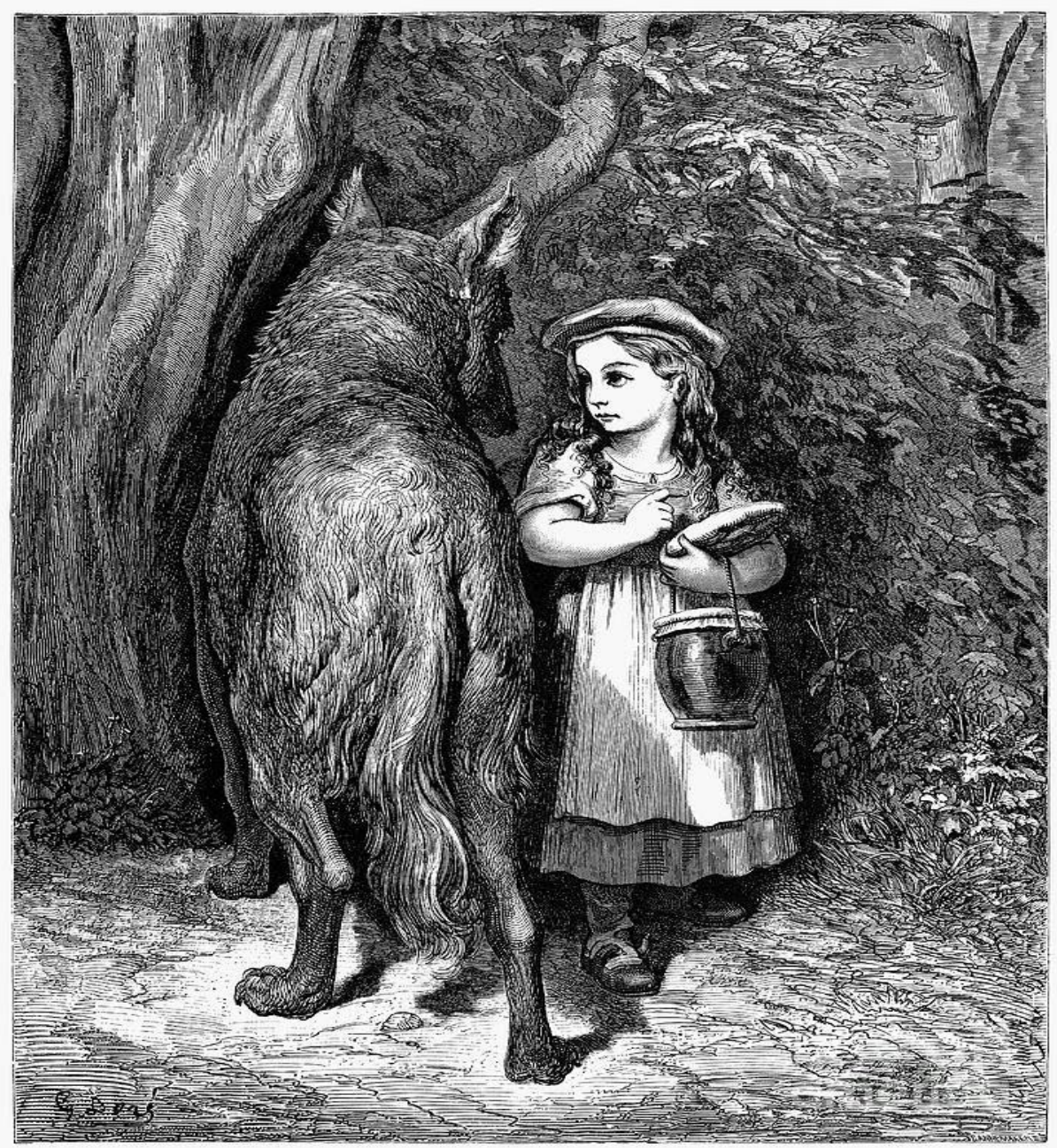

Disponível em https://fineartamerica.com/featured/6-little-red-riding-hood-gustave-dore.html Acesso em outubro de 2020.

- A seguir, o professor fará as seguintes perguntas oralmente aos alunos: 


\section{1- 0 que chama atenção de vocês nesta imagem? Por quê?}

2- Ela é uma ilustração de uma história famosa? Qual?

3-Vocês já leram, ouviram ou assistiram algo sobre essa história?

4- Qual é o enredo dessa história?

5- Quais são os personagens?

6- Onde essa história se passa?

7- Quando ela se passa?

8- Quanto tempo dura a ação?

Observação: Caso os alunos não entendam os termos usados, como, por exemplo, "personagem" e "enredo", o professor poderá explicá-los superficialmente. As perguntas não visam apenas a explorar o conhecimento dos alunos sobre a história de "Chapeuzinho Vermelho" a partir da imagem projetada, mas também introduzir de modo sucinto e superficial algumas categorias da narrativa como, por exemplo, personagens, espaço, tempo e enredo.

- Após a contextualização da história de "Chapeuzinho Vermelho", o professor falará sobre as suas origens na tradição oral, lançando a seguinte pergunta:

"Quem é o autor dessa história?" 
Observação: Provavelmente, os alunos não saberão responder, porque essa história não tem autores. Um aluno poderá até argumentar que tenha lido em um determinado livro; entretanto, o professor deverá explicar-Ihes que essas histórias vieram da tradição oral, de modo que foram compiladas primeiramente pelo escritor francês Charles Perrault, no ano de 1697. Já a segunda versão, também bastante conhecida, foi recontada pelos irmãos Jacob e Wilhelm Grimm no ano de 1812. Depois, ela vem sendo recontada de modos diferentes no decorrer do tempo por outros contadores de histórias. Todavia, a história da "Chapeuzinho Vermelho", assim como as outras histórias que fazem parte do acervo das narrativas primordiais, não foram criadas nem por Perrault nem pelos outros contadores de histórias; eles a recolheram da tradição oral e a recontaram por escrito.

- Após essa explicação, o professor perguntará oralmente aos alunos:

Vocês conhecem alguma história da tradição oral com versões diferentes? E de sua região, qual vocês conhecem?

\section{$2^{\circ}$ Momento}

- Para esse segundo momento, o professor informará aos alunos que serão lidas duas versões de "Chapeuzinho Vermelho". Antes de iniciar a leitura coletiva, que será feita em voz alta, será solicitado aos alunos que se prontifiquem a ler trechos do texto. A partir de cada leitura, os alunos deverão preencher o quadro seguinte, que deverá ser anexado ao diário de leitura. 


\begin{tabular}{|l|l|l|}
\hline \multicolumn{1}{|c|}{ Categorias } & $\begin{array}{c}\text { Versão de Charles } \\
\text { Perrault }\end{array}$ & $\begin{array}{c}\text { Versão dos Irmãos } \\
\text { Grimm }\end{array}$ \\
\hline Enredo & & \\
\hline Personagens & & \\
\hline Espaço & & \\
& & \\
\hline Tempo & & \\
& & \\
\hline
\end{tabular}

- Antes de iniciar a leitura, o professor projetará a capa do livro (Anexo 1) de onde foram tiradas as histórias, explorando-a oralmente, a partir das seguintes perguntas:

1- O que chamou a atenção de vocês nessa capa?

2- Qual é o título?

3- Qual é a editora responsável pela publicação desse livro?

4- De quem são os nomes que aparecem na capa?

5- Que outras histórias aparecem na capa?

6- Que informação na capa diz que no livro existem mais autores?

7- Que informação na capa diz que o livro contém outras histórias, além daquelas citadas na capa? 
Observação: O professor explicará que Perrault, Grimm e Andersen são escritores de contos infantis e que Ana Maria Machado é uma autora brasileira de livros infantis que compilou as histórias desses escritores e de outros para elaborar o livro Contos de Fadas: de Perrault, Grimm, Andersen \& outros (Anexo 1).

- Após a contextualização do professor, então, será iniciada a leitura da primeira obra, que se refere à versão do escritor francês Charles Perrault (Anexo 2).

- Após a leitura da versão de Perrault, os alunos preencherão a primeira parte do quadro. O professor, então, checará oralmente as respostas. Após esse momento, será iniciada a leitura da segunda versão dos Irmãos Grimm (Anexo 3).

- Terminada a leitura da versão dos Irmãos Grimm, os alunos preencherão a segunda parte do quadro e o professor checará as repostas ${ }^{1}$.

- Após o preenchimento do quadro, a ser realizado mediante cada leitura das versões, o professor debaterá oralmente com os alunos as diferenças das versões que foram completadas no quadro comparativo, a partir das seguintes perguntas:

1- O que chamou mais atenção de vocês na diferença entre as histórias? Por quê?

2- Uma das diferenças refere-se ao epílogo da história. Vocês sabem o que é epílogo?

3- A mudança no epílogo torna a história mais adequada a que tipo de público?

\footnotetext{
${ }^{1}$ A verificação das respostas nesse momento não objetiva checar o uso da norma padrão da língua portuguesa, mas apurar se os estudantes foram capazes de responder coerentemente às perguntas pertencentes ao texto explorado.
} 
Observação: O professor aproveitará para explicar aos alunos que o epílogo se refere ao desfecho ou conclusão da história. Desse modo, o professor estará inicialmente promovendo o processo de letramento literário nos alunos. 


\section{Etapa 1: Do acervo popular à adaptação}

Encerrada a etapa motivacional, o professor iniciará o momento seguinte com a exploração do texto as "Façanhas do Zé Burraldo", que faz parte do acervo dos contos populares e se encontra no livro Histórias de bobos, bocós, burraldos e paspalhões, do autor Ricardo Azevedo. Será também trabalhada uma adaptação do texto "Façanhas de Zé Burraldo", constante na obra fímica Pequenas Histórias do diretor Helvécio Ratton.

O trabalho com a exploração do texto "Façanhas do Zé Burraldo" será realizado em cinco momentos, pois o conto será fragmentado, propositalmente, com o intuito de se promover nos alunos maior interação com o texto. No quinto momento, será explorada a adaptação do texto constante na obra fímica Pequenas Histórias do diretor Helvécio Ratton.

\section{$1^{\circ}$ Momento}

Tempo: 2 aulas/50 $\mathrm{min}$

- Antes de iniciar a leitura do texto, o professor apresentará uma noção sucinta de conto $^{2}$ e de suas características, escrevendo no quadro a seguinte conceituação que deverá ser anotada pelo aluno em seu diário de leitura.

\section{Gênero Textual Conto}

Conceito: Narrativa curta que apresenta apenas um conflito ou ação, que se desenvolve em um determinado espaço, comumente restrito a poucos ou a um único ambiente, em curta duração de tempo, limitado por dias ou horas, contendo um número bem reduzido de personagens, e que é contada, ou seja, narrada por alguém, que pode ou não participar da história (conceito elaborado a partir da obra $A$ criação literária - introdução à problemática da literatura do autor Massaud Moisés, 1970).

\footnotetext{
${ }^{2}$ A Banca Examinadora sugeriu como uma proposta que, ao invés de o professor apresentar o conceito de conto, seria mais interessante que ele, por meio da mediação, instigue os alunos à construção desse conhecimento.
} 
- Após a breve explicação sobre Conto, o professor informará aos alunos que eles irão interagir com um texto que faz parte do acervo popular. Nesse momento, será mostrada aos alunos a capa do livro, de modo que o docente esclarecerá a eles que o texto, a ser explorado para a dinâmica dessa aula, faz parte dele.

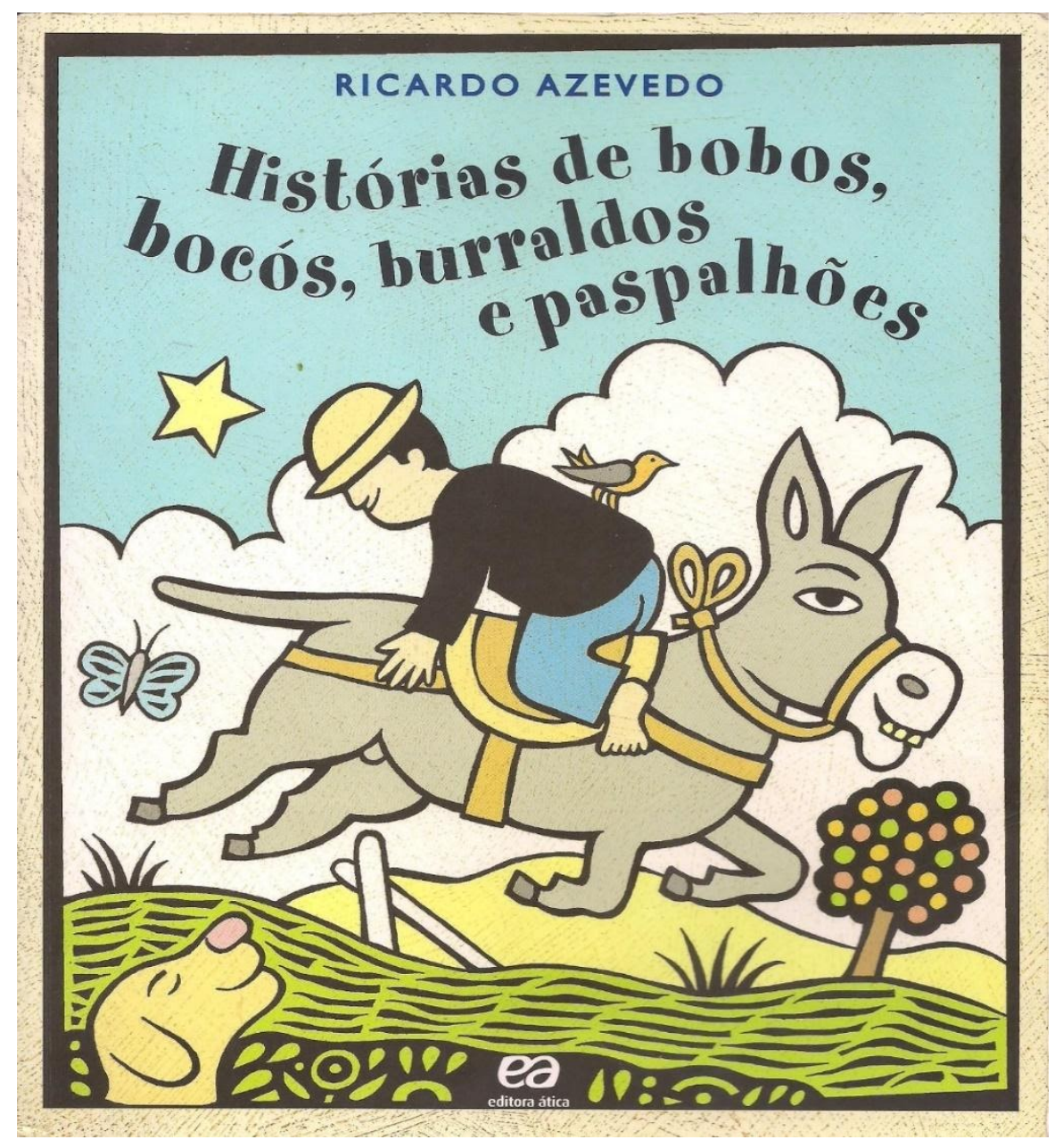

llustração de Ricardo Azevedo.

AZEVEDO, R. Histórias de bobos, bocós, burraldos e paspalhões. 1. ed. São Paulo: Ática, 2009.

- Após a apresentação do livro, o docente projetará no quadro a ilustração da página seguinte e fará aos alunos as perguntas sobre ela (vide pág. 19) para que eles respondam oralmente. 
FAÇANHAS DO ZÉ BURRALDO

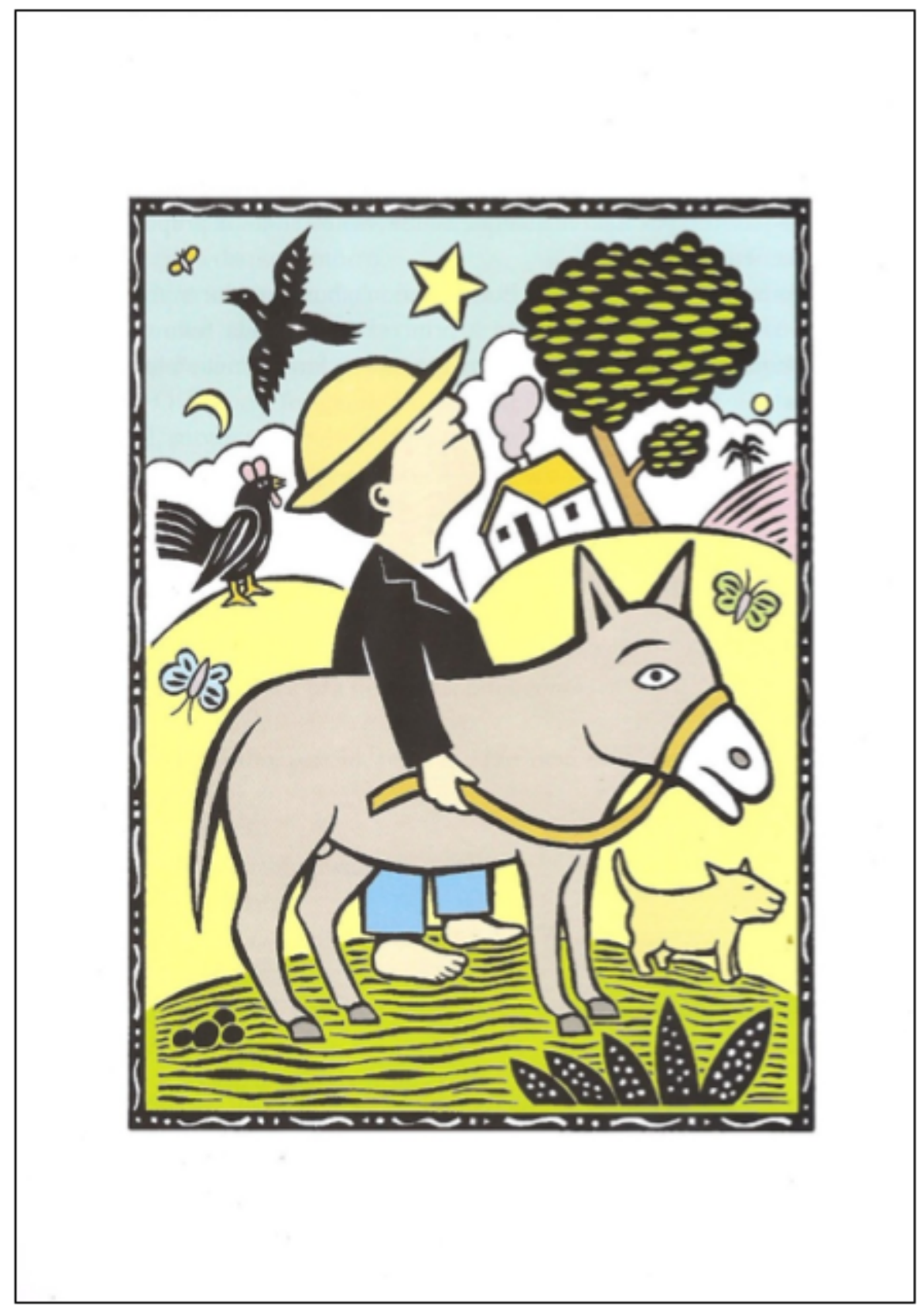

llustração de Ricardo Azevedo.

AZEVEDO, R. Histórias de bobos, bocós, burraldos e paspalhōes. 1. ed. Săo Paulo: Ática, 2009. 
1- O que chama atenção na ilustração? Por quê?

2- O que o título do texto e a ilustração sugerem?

3- Observando o título, o que vocês entendem por "Façanhas"?

4- A partir do título, já podemos deduzir o nome do personagem principal. A palavra "Burraldo" foi utilizada para qualificar a personagem principal. Qual seria o sentido dessa palavra para o texto que iremos ler?

5- A partir da ilustração e do título, o que vocês deduzem sobre o enredo da história? Quais hipóteses podemos elaborar sobre o texto que iremos ler?

- O professor ouvirá atentamente as colocações dos alunos referentes às perguntas. Em relação às questões número 4 e 5 , ele deverá anotar na lousa algumas respostas sugeridas pelos alunos, para que elas sejam analisadas ao fim da leitura do primeiro fragmento.

- Após a dinâmica com a ilustração, o professor entregará aos alunos um fragmento impresso do texto para ser anexado ao diário de leitura (Anexo 4). Será realizada uma leitura coletiva, em voz alta, devendo os alunos se prontificarem para participar dela. Após o término da leitura desse primeiro momento, serão feitas as seguintes perguntas para que os alunos anotem e respondam no diário de leitura. Os discentes terão alguns minutos para respondê-las. 
1- Que fato desencadeia a saída do personagem principal de casa?

2- Quais acontecimentos marcam o início das aventuras do personagem principal?

3- A partir desse fragmento, as hipóteses que vocês fizeram anteriormente sobre o sentido da palavra "Burraldo", confirmaram-se? Por quê?

4- A partir desse fragmento, as hipóteses que vocês levantaram anteriormente, sobre o enredo da história, confirmaram-se ou não? Por quê?

5- Agora que conhecemos um pouco sobre Zé Burraldo, o que vocês imaginam que vai acontecer com ele?

- O professor checará oralmente as respostas dos alunos, principalmente em relação às questões 3 e 4 . Em relação à questão número 5 , o docente deverá ouvir atentamente as hipóteses e pedir que as anotem no diário de leitura para serem retomadas mais adiante.

\section{$2^{\circ}$ Momento}

Tempo: 2 aulas/50 $\mathrm{min}$

- O professor pedirá aos alunos que façam oralmente um resumo do primeiro fragmento lido.

- Após os alunos recordarem o trecho do texto, o professor prosseguirá com a leitura do segundo fragmento. Antes de entregar o texto (Anexo 5), o docente comunicará aos alunos que a leitura será realizada coletivamente, em voz alta, e que eles deverão se dispor para participarem dela. Após a informação, será entregue à turma o novo fragmento do texto que deverá ser anexado ao diário de leitura deles. 
- Após a leitura, o professor verificará se as hipóteses levantadas antes da leitura do fragmento se confirmaram e solicitará aos alunos que anotem as seguintes perguntas referentes ao fragmento lido no diário de leitura. Os alunos terão alguns minutos para respondê-las.

1- A cada fragmento lido, vocês percebem o porquê de o personagem receber o sobrenome "Burraldo". Esse sobrenome funciona como característica marcante do personagem. $\mathrm{O}$ que isso exemplifica no fragmento lido?

2- Seguindo as pistas do texto, vocês acham que o povo ria da inocência do Zé Burraldo em acreditar que realmente o burro fosse mágico, ou por acharem que ele fosse um comediante? Justifique.

3- De acordo com o que vocês já conhecem sobre o personagem Zé Burraldo, o que imaginam que acontecerá com ele como ator? Quais hipóteses vocês levantam?

- O professor verificará as respostas dos alunos e deverá anotar na lousa a questão número 3 para depois checar com os discentes se as hipóteses se confirmarão, conforme leitura do próximo fragmento.

\section{$3^{\circ}$ Momento}

Tempo: 2 aulas/50 min

- O professor informará aos alunos que eles irão trabalhar com mais um fragmento do texto as "Façanhas do Zé Burraldo". Antes de iniciar a leitura do fragmento, o professor projetará na lousa a imagem seguinte e fará oralmente aos alunos a pergunta sobre ela (vide pág. 22), com o objetivo de relembrar o fragmento lido na aula anterior. 


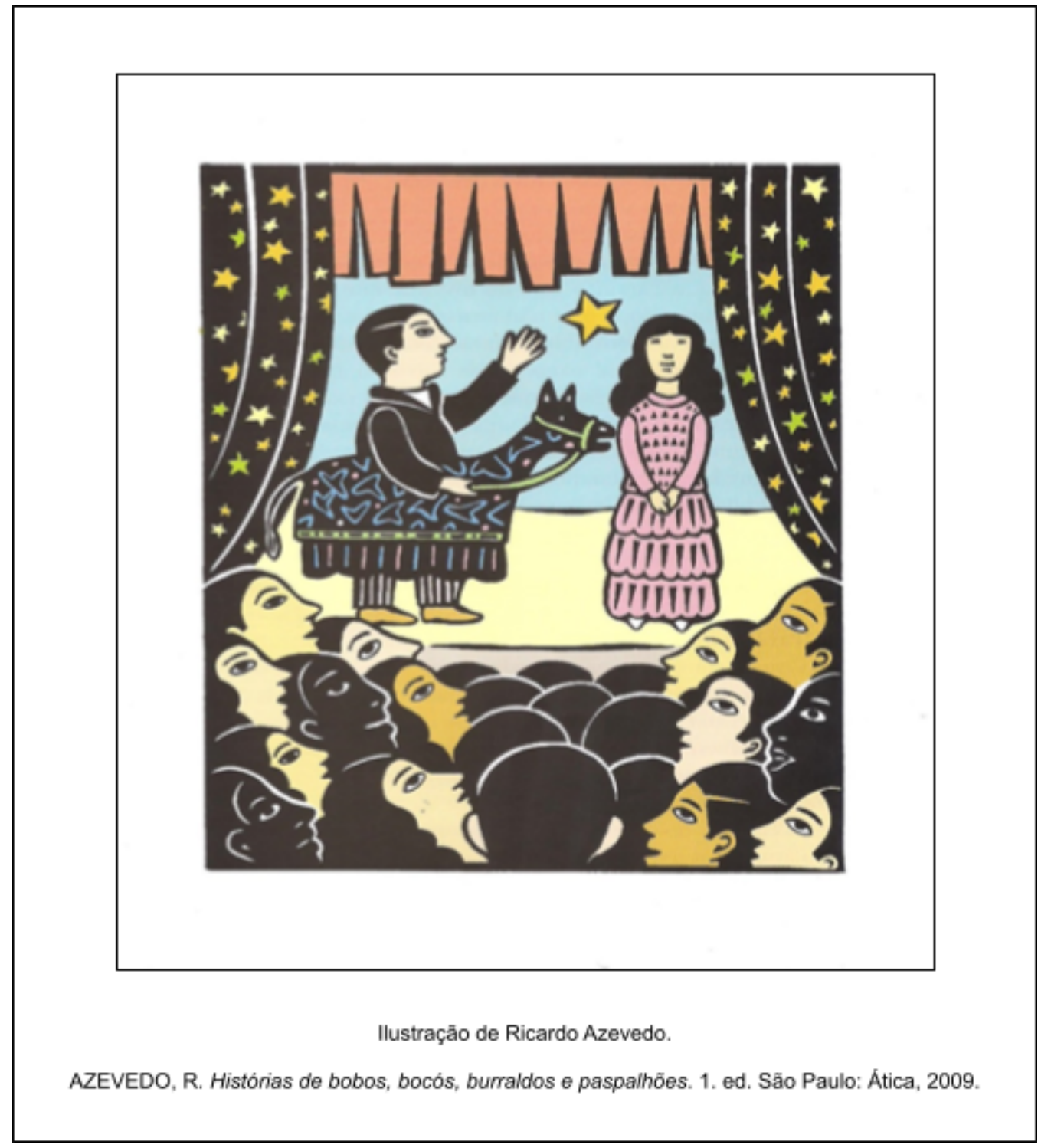

Sobre o fragmento que lemos na aula anterior, vimos que o nosso aventureiro Zé Burraldo irá se envolver em uma nova façanha. Entretanto, para darmos continuidade à história desse personagem, vamos relembrar alguns acontecimentos. Que relação podemos fazer entre a ilustração e o fragmento que lemos na aula anterior, sobre o personagem Zé Burraldo? 
- Antes de entregar o texto (Anexo 6), o docente comunicará aos alunos que a leitura será realizada coletivamente, em voz alta, e que eles deverão se dispor a participarem dela. Após a informação, será entregue à turma o novo fragmento do texto que deverá ser anexado ao diário de leitura deles.

- Após a leitura, o professor verificará com os alunos as hipóteses que foram elaboradas, de modo a observar se houve ou não a confirmação delas. Depois, o professor solicitará aos alunos que anotem as seguintes perguntas referentes ao fragmento lido no diário de leitura. Os alunos terão alguns minutos para respondê-las.

1- Que acontecimento faz com que a peça tome um rumo diferente do qual o diretor havia previsto?

2- Qual foi a percepção do público com a atuação do Zé Burraldo?

3- Qual foi a percepção inicial do diretor da peça perante a atuação do Zé Burraldo? Ela permaneceu a mesma? Por quê?

4- Para vocês, de que modo Zé Burraldo encarou a própria participação na peça teatral? Justifique.

- Após os alunos responderem às questões no diário de leitura, o professor checará oralmente as respostas.

\section{$4^{\circ}$ Momento}

Tempo: 4 aulas/50 min

- O professor informará aos alunos que eles irão trabalhar com o último fragmento do texto as "Façanhas do Zé Burraldo". Antes de iniciar a leitura do fragmento, o professor projetará na lousa a imagem seguinte, e fará oralmente aos alunos a pergunta sobre ela (vide pág. 24). 


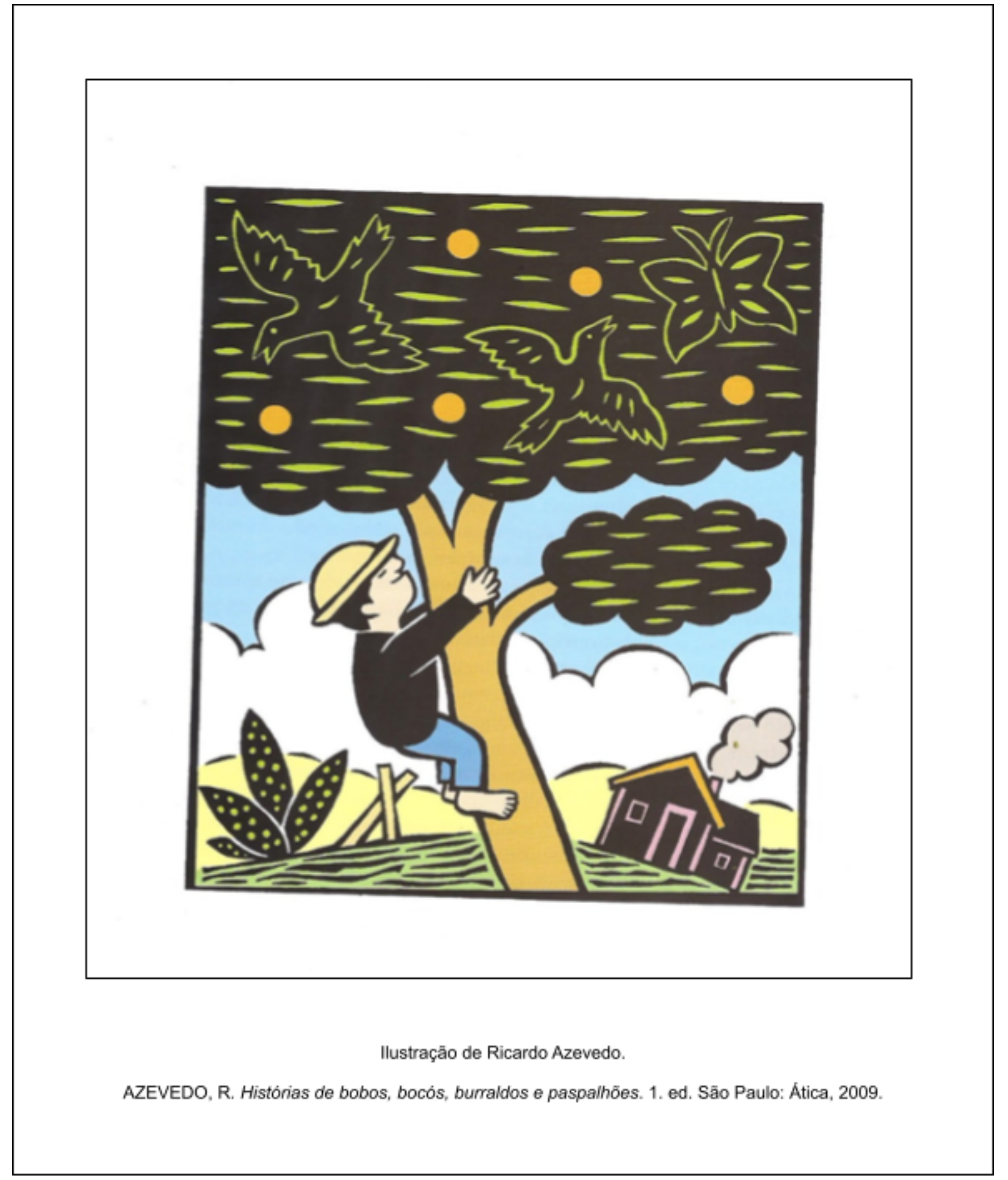

Assim, chegamos ao último fragmento do texto sobre o nosso aventureiro Zé Burraldo. Pelo que já vimos desse personagem, podemos esperar as façanhas mais inusitadas. Desse modo, a partir da ilustração, gostaria de ouvir de vocês:

O que vocês acham que irá acontecer com Zé Burraldo? 
- O professor ouvirá atentamente as respostas dos alunos e anotará também algumas sugestões levantadas pelos alunos sobre o que irá acontecer com o personagem Zé Burraldo. Antes de entregar o texto (Anexo 7), o docente comunicará aos alunos que a leitura será realizada coletivamente, em voz alta, e eles deverão se dispor a participarem dela. Após a informação, será entregue à turma o último fragmento do texto que deverá ser anexado ao diário de leitura deles.

- Após a leitura, o professor perguntará oralmente aos alunos:

1- A hipótese que vocês levantaram confirmou-se com o que vocês acabaram de ler?

2- Levando em consideração todos os fragmentos que exploramos em nossas aulas sobre as "Façanhas do Zé Burraldo", o epílogo da história está de acordo com o perfil do nosso personagem Zé Burraldo? Por quê?

3- De que modo o desfecho da história poderia ser diferente?

- O professor checará oralmente as respostas e depois fará uma nova pergunta que deverá ser anotada e respondida pelo aluno no diário de leitura.

Agora que conhecemos toda a história de Zé Burraldo, quais os aspectos do conceito de conto, observados em nossas primeiras aulas, vocês encontram no texto lido?

- O professor dará aos alunos alguns minutos para responderem à pergunta e, após, ele conferirá oralmente as respostas, observando se os discentes foram capazes de relacionar os aspectos do conceito de conto com os que aparecem no texto lido. 
- A seguir, o professor solicitará aos alunos que se dividam em 5 grupos com 4 alunos, e apresentará a seguinte proposta de atividade:

Agora que vocês já conhecem toda a história de Zé Burraldo, cada grupo deverá modificar o desfecho da história, isto é, irão alterar somente o último parágrafo, escrevendo um novo final para ela.

- Os grupos terão um tempo para desenvolverem a atividade proposta no diário de leitura. Durante o período em que os alunos estiverem compondo o novo epílogo, o professor deverá passar pelos grupos para sanar as dúvidas que eles apresentarem em relação à composição do parágrafo de desfecho. Após realizarem a tarefa, cada grupo deverá compartilhar suas ideias com os outros, realçando, na leitura em voz alta, os novos epílogos produzidos.

\section{$5^{\circ}$ Momento}

Tempo: 4 aulas $/ 50 \mathrm{~min}$

- Para dar continuidade a esse momento, o docente levará os alunos para a sala de vídeo. Ele informará aos discentes que eles assistirão a um trecho do filme Pequenas Histórias do diretor Helvécio Ratton. Também explicará a eles que o filme retoma quatro pequenas histórias que foram recolhidas da cultura popular e foram adaptadas para uma obra filmica. Uma dessas histórias adaptadas, que faz parte do filme, é as "Façanhas de Zé Burraldo". Para enriquecer a apresentação do trecho, o professor mostrará aos alunos a capa do filme (Anexo 8). Antes de iniciar o trecho do filme com a história "Façanhas de Zé Burraldo", o professor aproveitará para explicar oralmente e de modo sucinto aos discentes o que é adaptação ${ }^{3}$, elucidando estes conhecimentos mostrados neste quadro que será projetado na lousa.

\footnotetext{
${ }^{3}$ A Banca Examinadora sugeriu como uma proposta que, ao invés de o professor apresentar o conceito de adaptação, seria mais interessante que ele, por meio da mediação, instigue os alunos à construção desse conhecimento.
} 
Adaptação é um modo de recontar uma determinada história já bastante conhecida pelo público, utilizando-se o mesmo suporte ou mesmo outras mídias. Pode haver modificações significativas em relação à obra original, o que faz da adaptação uma obra nova com características próprias. Essas modificações, que diferenciam a obra original da adaptada, evidenciam-se desde o ponto de vista até as escolhas de quem a produz. Essas variações podem aparecer nos personagens, na descrição visual dos cenários, nos espaços em que ocorre a história, na duração, em quem conta a história e até mesmo no enredo que motiva a ação (conceito elaborado a partir da obra Teoria da adaptação da autora Linda Hutcheon, 2013).

- Após a explicação oral sobre adaptação, antes de o professor projetar o trecho "Façanhas de Zé Burraldo", constante na obra filmica Pequenas Histórias (Anexo 9), ele mostrará aos alunos um quadro (Anexo 10) que deverão preencher, apontando as semelhanças e as diferenças entre a história que leram na obra de Ricardo Azevedo e do trecho que irão assistir. Logo após, projetará o trecho.

- Depois da projeção, o professor apresentará aos alunos uma imagem do filme contendo a reprodução da fala inicial (3min8s até $3 \min 36 s$ ) da personagem, que a atriz Marieta Severo interpreta, como contadora de história na obra filmica Pequenas Histórias, do diretor Helvécio Ratton. O docente fará a leitura das falas da personagem e indagará oralmente aos alunos:

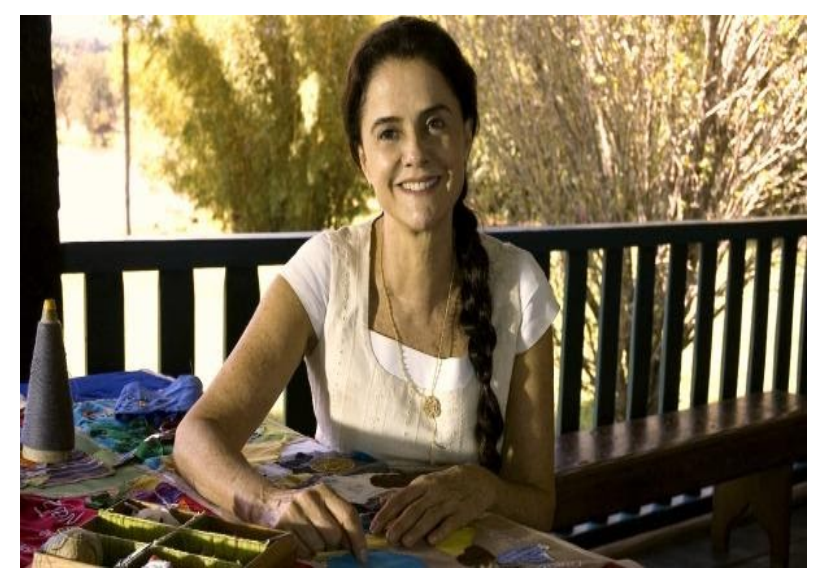

"Tem gente que diz que contar uma história é como dar mais uma volta no parafuso. Mas eu acho que isso é conversa de homem. Para mim, quem conta um conto dá mais um ponto. Será que quem conta um conto aumenta um ponto? Sei lá, o que eu sei é que cada vez que conto uma história, ela sai um pouquinho diferente". 
A qual conceito que vocês já viram, referem-se as falas da personagem interpretada pela atriz Marieta Severo?

Observação: Com essa indagação, o docente espera que os alunos consigam relacionar as falas da personagem com aspectos do conceito de adaptação explicado pelo professor no início do quinto momento.

- O professor ouvirá atentamente as respostas dos alunos, observando se eles conseguiram relacionar as colocações da personagem com aspectos do conceito de adaptação, já explanado no início desse momento.

- Após o docente checar as respostas, entregará aos alunos uma folha impressa, que deverá ser anexada ao diário de leitura deles, para que eles preencham o quadro que já foi mostrado (Anexo 10), relacionando as semelhanças e as diferenças entre o texto lido e o trecho que acabaram de assistir, conforme os elementos destacados no quadro.

- O professor dará aos alunos um tempo para poderem preencher o quadro (Anexo 10) e, após, checará as respostas.

- Após a correção do quadro, o professor realizará uma atividade sobre alguns pontos da obra que eles acabaram de assistir, perguntando oralmente:

1- O que mais Ihes chamou a atenção entre as duas versões, as semelhanças ou as diferenças?

2- Na opinião de vocês, por que houve modificações na transposição do conto, que lemos em aula, para o texto fílmico, a que assistimos?

3-Levando em consideração as duas obras: o conto que lemos e o trecho a que assistimos, qual delas para vocês foi mais interessante? Por quê? O que levou vocês a pensarem assim? 
- O professor ouvirá atentamente as respostas dos alunos, de forma a observar se eles conseguiram perceber que há algumas semelhanças e diferenças entre o texto lido e a obra filmica. É importante que percebam que adaptações são obras distintas, que não necessariamente têm de ser fiéis entre si, em todos os aspectos. 


\section{Etapa 2: Do "causo" à adaptação}

Encerrada a etapa com a exploração do conto "Façanhas de Zé Burraldo" do autor Ricardo Azevedo e do trecho presente na obra Pequenas Histórias do diretor Helvécio Ratton, o professor prosseguirá no processo de letramento literário e de ampliação de repertório com a exploração do texto a "Procissão das Almas", que também faz parte do acervo dos contos populares e se encontra no livro Contos de Mistério \& Assombros do autor Nelson Albissú. Será também trabalhada uma adaptação do conto "Procissão das Almas", constante na obra fímica Pequenas Histórias do diretor Helvécio Ratton.

\section{$1^{\circ}$ Momento}

Tempo: 4 aulas/50 min

- O trabalho com a exploração do texto "Procissão das Almas" ocorrerá da seguinte forma:

$\checkmark$ O professor informará aos alunos que farão a leitura de um causo que foi compilado da tradição oral brasileira e que foi transcrito em formato de gênero textual Conto pelo autor Nelson Albissú.

$\checkmark$ Antes de iniciar a leitura do texto (Anexo 11), o professor questionará aos alunos se eles se recordam do conceito de conto. Após ouvir as respostas dos alunos, o professor projetará no quadro a imagem seguinte e fará oralmente aos alunos as perguntas (vide pág. 31) sobre ela. 


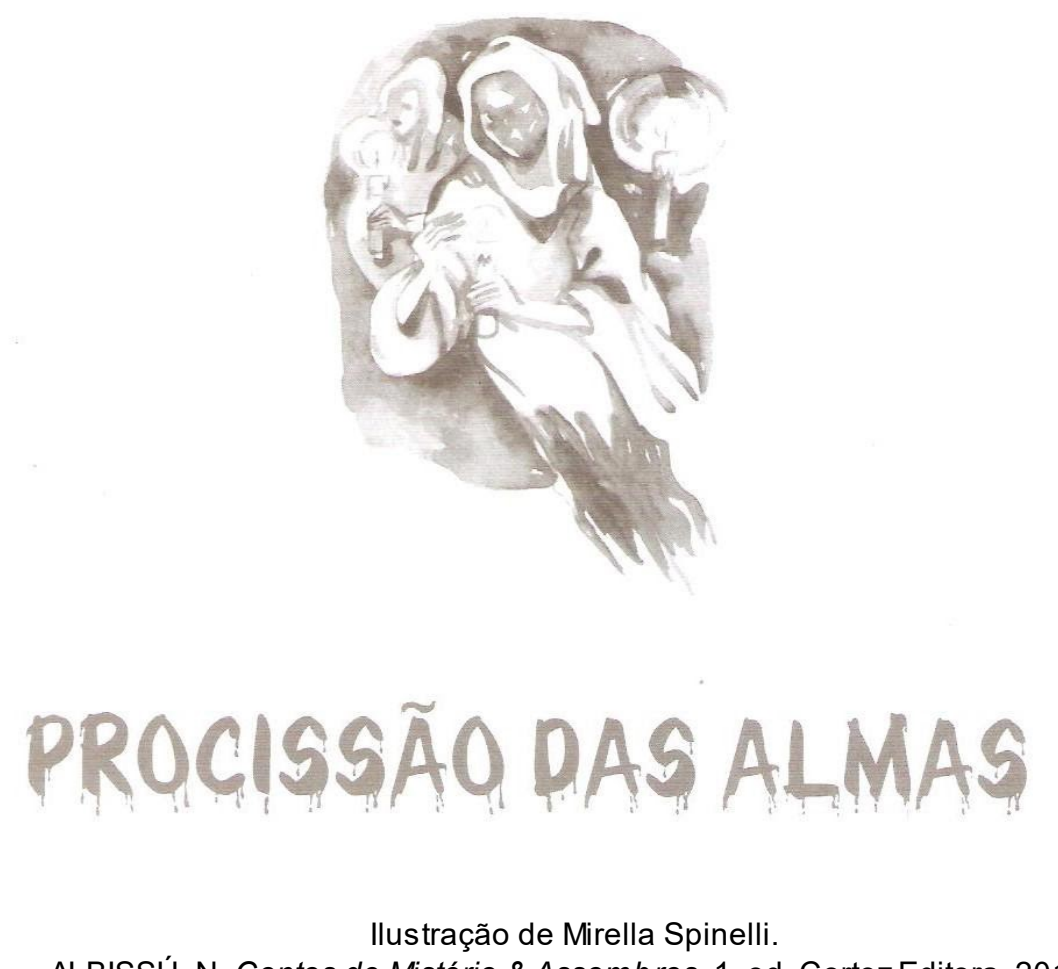

ALBISSÚ, N. Contos de Mistério \& Assombros. 1. ed. Cortez Editora, 2012.

1- O que chama atenção na imagem? Por quê?

2- O que sugere o modo como está escrito o título da história? Por quê?

3- Que relação pode-se estabelecer entre a ilustração e o que está escrito?

4- A partir da ilustração e o que está escrito, o que vocês acham que será contado na história? Quais hipóteses podemos elaborar sobre o texto que iremos ler?

- O professor deverá ouvir atentamente as colocações dos alunos, referentes às perguntas. Em relação à questão número 4, ele deverá anotar no quadro algumas hipóteses sugeridas pelos alunos, para que elas sejam analisadas ao final da leitura. 
- Após a dinâmica com a imagem, o professor colocará numa parte do quadro as seguintes perguntas que se referem ao texto (Anexo 11). As questões deverão ser anotadas no diário de leitura pelo aluno:

1- Qual é o título da história?

2- Qual é o nome do autor?

3- Qual é a relação entre o título e o texto?

4- Onde se passa a história?

5- Há muitos ou poucos personagens na história? Quem são eles?

6- A duração da história é curta ou longa?

7- Qual é o conflito da história?

8- Quem é o narrador? Esse narrador participa da história, ou a conta?

9- Qual é o problema que envolve o personagem principal?

10 - A hipótese que você levantou, confirmou-se ou não? Justifique.

11 - O que você achou do desfecho da história? Por quê?

- Depois que os alunos copiarem as perguntas, o professor entregará a eles o texto na íntegra. Antes, explicará que o texto será lido em voz alta e que a leitura será compartilhada, de modo que eles se prontifiquem também para participar espontaneamente da leitura. $\mathrm{O}$ docente iniciará a leitura e depois solicitará a outros alunos que a continuem. 
- Depois de realizada a leitura, o professor dará aos alunos alguns minutos para responderem às perguntas. Após esse tempo, ele checará oralmente com os alunos se as hipóteses que eles sugeriram se confirmaram ou não. $A$ atividade segue com o docente verificando as respostas das outras questões e lançando nova pergunta que deverá ser também anotada e respondida pelo aluno no diário de leitura.

Como já estudamos em aulas anteriores, vimos o que é conto e algumas características dele. Podemos afirmar que o texto "Procissão das Almas" é um conto? Por quê?

- O professor dará aos alunos alguns minutos para responderem à pergunta anterior. Em seguida, conferirá as respostas, observando se os discentes foram capazes de relacionar os aspectos do conceito de conto com os que aparecem no texto lido.

- Para dar continuidade a esse momento, o docente levará os alunos para sala de vídeo. Informará aos discentes que eles assistirão a um trecho do filme Pequenas Histórias (Anexo 9) do diretor Helvécio Ratton. Também explicará que o filme reúne quatro pequenas histórias que foram recolhidas da cultura popular e adaptadas para uma obra filmica. Uma dessas histórias adaptadas, que faz parte do filme, é a "Procissão das Almas". Antes de iniciar o trecho do filme, o professor indagará aos alunos sobre o que eles se recordam do conceito de adaptação. O professor deverá ouvir atentamente as colocações dos alunos, auxiliando-os no processo de recordação e recuperação do conceito, apresentando exemplos que fazem parte do repertório deles.

- Após a verificação das respostas dos alunos, antes de o professor projetar o trecho "Procissão das Almas", constante na obra filmica Pequenas Histórias, ele mostrará aos alunos o quadro (Anexo 12) que deverão preencher, apontando as semelhanças e as diferenças entre a história que leram na obra do Nelson Albissú e do trecho a que irão assistir. Logo após, deverá projetar o trecho. 
- Depois da projeção, o professor entregará aos alunos uma folha impressa, que deverá ser anexada no diário de leitura deles, para que eles preencham o quadro já apresentado (Anexo 12), relacionando as semelhanças e as diferenças entre o texto lido e o trecho que acabaram de assistir, conforme os elementos destacados no quadro.

- O professor dará aos alunos um tempo para preencherem o quadro (Anexo 12), devendo, após, verificar a pertinência das respostas.

- Após a correção do quadro, o professor realizará uma atividade sobre alguns pontos da obra que eles acabaram de assistir, perguntando oralmente:

1-Há mais diferenças ou semelhanças entre as duas versões? Em seu ponto de vista, a versão fílmica é uma adaptação ou uma obra distinta?

2-Na sua opinião, por que houve modificações na transposição do conto, que lemos em aula, para o texto fílmico, a que assistimos? A obra fílmica condensa ou expande o texto escrito?

3-Levando em consideração as duas obras, o conto que lemos e o trecho a que assistimos, qual delas produziu em você maior sensação de medo ou espanto? Por quê? O que levou você a pensar assim?

- O professor ouvirá atentamente as respostas dos alunos, de forma a observar se eles conseguiram perceber que há diferenças entre as duas linguagens; a literatura e o cinema. Portanto, modificações precisam ser feitas. É importante terminar a discussão apontando que houve uma grande expansão na obra filmica. 


\section{Etapa 3: Uma adaptação fílmica}

Encerrada a etapa com a exploração do conto "Procissão das Almas" do autor Nelson Albissú e do trecho presente na obra Pequenas Histórias do diretor Helvécio Ratton, o professor dará prosseguimento ao processo de letramento literário e de ampliação de repertório a partir da adaptação filmica O Homem Nu do Diretor Hugo Carvana (1997). Informamos que, para a composição das atividades, algumas cenas do filme precisaram ser editadas (Anexo 13), para que se adequassem à faixa etária de todos os alunos e não causassem constrangimentos a docentes de uma comunidade muito conservadora.

O trabalho com a exploração da obra fímica O Homem Nu será realizado em três momentos, ou seja, será estruturado em três partes, para se obter uma mediação mais eficaz da obra cinematográfica junto aos alunos, de modo que eles possam perceber que na adaptação filmica há uma expansão ou redução das categorias da narrativa: enredo, personagem, espaço e tempo, pois são as que mais se destacam no filme.

\section{$1^{\circ}$ Momento}

Tempo: 4 aulas/50 $\min$

- O trabalho com a exploração da obra filmica O Homem $\mathrm{Nu}$, acontecerá da seguinte forma:

$\checkmark$ O professor levará os alunos para sala de vídeo. Contudo, antes de iniciar a primeira parte da projeção do filme, será explicado aos alunos que eles assistirão a uma obra filmica dirigida por Hugo Carvana que, além de ter sido ator, também foi um grande diretor de cinema e televisão. Como processo de motivação para preparar os alunos para ambientação do filme, também será mostrado o cartaz do filme (Anexo 14), que será explorado a partir de perguntas, que serão feitas aos discentes para que respondam oralmente. O professor solicitará aos alunos que observem atentamente o cartaz (Anexo 14) do filme e fará as seguintes perguntas para que eles respondam oralmente: 
1- O cartaz é apropriado para que tipo de filme?

Observação: Para auxiliarem os alunos a elaborarem a resposta para essa questão, o professor explicará que no cinema também há gêneros que servem para classificar a natureza das obras filmicas, como, por exemplo, ação, animação, aventura, comédia, documentários, ficção científica, entre outros gêneros.

2- Para vocês, que situação levou o homem a ficar nu?

3- A partir da capa, qual seria o enredo, ou seja, os fatos que constroem a história do filme? Quais hipóteses podemos elaborar sobre o filme que iremos ver?

- O professor deverá ouvir atentamente as colocações dos alunos, referentes às questões. Em relação à questão número 3, solicitará aos discentes que anotem as hipóteses no diário de leitura, para posteriormente checá-las. Após a dinâmica com a capa do filme, o professor projetará a primeira parte do filme, cujo tempo é de 00h, 00min e 00s até $24 \mathrm{~min}$ e $36 \mathrm{~s}$ (inclui do início do filme até a cena em que Silvio Proença abre a porta do apartamento de Marialva para pegar o pão na área).

- Para essa primeira parte projetada, o professor verificará as hipóteses levantadas anteriormente pelos alunos e fará os novos questionamentos, com o objetivo de identificar os fatos iniciais, os personagens, o tempo e o espaço, de modo a situar os discentes em relação ao enredo da obra filmica.

- O professor entregará uma ficha impressa (Anexo 15) com as questões, para que os alunos a respondam. O docente realizará a leitura das questões e solicitará aos alunos que se coloquem oralmente. Somente após o debate das questões, é que os alunos formularão a resposta por escrito no diário de leitura. 
- Durante a resolução das atividades, o professor deverá circular pela sala, visitando as duplas, para sanar as dúvidas que surgirem.

- O professor fará a verificação das respostas oralmente, intervindo, quando necessário, para esclarecer alguns aspectos da obra cinematográfica.

\section{$2^{\circ}$ Momento}

Tempo: 4 aulas/50 $\mathrm{min}$

- O professor levará os alunos novamente para sala de vídeo. Explicará a eles que dará continuidade ao filme, mas, antes, pedirá aos alunos que façam oralmente um resumo da primeira parte a que assistiram.

- Após os discentes recordarem a primeira etapa do filme, o professor iniciará a segunda, começando a projeção a partir dos $24 \mathrm{~min}$ e 36 s que irá ser projetada até aos 58min e 47s (refere-se à cena que Silvio Proença abre a porta do apartamento de Marialva e sai para pegar o pão, ficando preso do lado de fora até a cena em que ele chega ao apartamento onde realmente mora e toca a campainha).

- Em seguida, o professor proporá as atividades (Anexo 16). O objetivo é que os discentes possam perceber o desenrolar do conflito que envolve o personagem central. Também haverá uma mediação para a compreensão do tempo, do espaço e de outros personagens.

- A mediação ocorrerá com o professor entregando aos alunos uma ficha impressa com as atividades (Anexo 16). Antes, o professor solicitará aos discentes que se organizem em duplas para trocarem informações sobre o trecho a que assistiram. Mesmo trabalhando em dupla, cada aluno deverá ter sua ficha de atividade individual, a ser anexada no diário de leitura.

- O professor lerá as questões e solicitará aos alunos que participem oralmente. Somente após o debate das questões, é que os alunos formularão a resposta 
por escrito no diário de leitura. Durante a resolução das atividades, o professor deverá circular pela sala, visitando as duplas, para sanar as dúvidas que surgirem.

- Finalizando a mediação do segundo trecho visto pelos alunos, será pedido que eles continuem organizados em duplas, e que realizem uma produção escrita conforme orientação seguinte:

Tendo em vista a cena constante no exercício número 2 , redija um parágrafo modificando o fato que levou o personagem principal a ficar nu. Não se esqueçam de que esse parágrafo precisa estar coerente com o enredo da história.

Observação: Para essa atividade, o professor, além de solicitar aos alunos que voltem ao exercício 2 para visualizarem a cena (Anexo 17), ele poderá projetá-la na lousa. Durante o processo que as duplas estiverem produzindo, é importante que o professor circule pela sala, visitando-as, para sanar e orientar quanto às dúvidas que surgirem.

- Depois de realizada a tarefa, o professor pedirá que um dos integrantes da dupla faça oralmente a leitura da produção escrita.

\section{$3^{\circ}$ Momento}

Tempo: 4 aulas/50 min

- Dando continuidade à exploração da obra filmica, o professor levará os alunos à sala de vídeo e informará a eles que projetará a última parte do filme, começando a projeção a partir dos 58 min e $47 \mathrm{~s}$, projetando-o até $1 \mathrm{~h}, 13 \mathrm{~min}$ e 20s (refere-se à cena em que ele chega ao apartamento onde realmente mora e flagra Mendonça e a esposa juntos até a cena final em que Mendonça é capturado pela polícia como o homem nu que corria pela cidade). Antes de iniciar a projeção, o professor pedirá aos alunos que façam oralmente um resumo da segunda parte a que assistiram. 
- Logo após a projeção da última parte do filme, será proposto aos alunos que se organizem em dupla. Cada aluno da dupla receberá uma folha (Anexo 18) com atividades referentes ao filme; esta deverá ser anexada ao diário de leitura.

- O professor lerá as questões e solicitará aos alunos que se manifestem oralmente, somente após o debate de cada questão. Deverão formular a resposta por escrito no diário de leitura. Durante o processo de resolução das atividades, o professor deverá circular pela sala para atender as duplas, de acordo com as dúvidas que surgirem.

- Nessa etapa, com as atividades propostas (Anexo 18), visa-se a que os alunos percebam como a estrutura do enredo com o auxilio dos outros elementos da narrativa (tempo, espaço, personagem) se desenrolam para o desfecho da ação filmica.

- Depois de realizadas as tarefas, o professor analisará oralmente as respostas dos alunos, sanando as dúvidas que surgirem durante a correção. 


\section{Etapa 4: Da adaptação ao texto original}

Encerrada a etapa com a exploração da obra filmica O Homem $\mathrm{Nu}$, do diretor Hugo Carvana (1997), o professor iniciará o momento seguinte com o conto $O$ Homem $\mathrm{Nu}$, do escritor Fernando Sabino. Os objetivos dessa etapa visam a que os discentes sejam capazes de perceber que o filme é uma obra adaptada do conto. Além disso, espera-se que os alunos reconheçam as similitudes ou as diferenças entre o filme e o conto, a partir da análise das categorias da narrativa mais abordadas em nossos estudos (enredo, espaço, tempo e personagem), que contribuem para a originalidade da obra cinematográfica. Para esse momento, também, serão retomados o conceito de adaptação e de conto, já explorados anteriormente, para auxiliar os alunos durante a mediação.

\section{$1^{\circ}$ Momento}

Tempo: 4 aulas $/ 50$ min

- Para o desenvolvimento dessa etapa, o professor, primeiramente, projetará na lousa o cartaz do filme (Anexo 14) e fará o seguinte questionamento para que os alunos respondam oralmente:

Observem novamente o cartaz do filme e aponte as informações que aparecem nele.

Observação: Com essa questão, o professor objetiva que os alunos não somente identifiquem o nome do filme, do diretor, dos atores e seus respectivos personagens, mas percebam que o filme é uma obra adaptada, pois aparece uma informação no cartaz, mostrando que ele é uma adaptação de um conto de Fernando Sabino.

- Após checar oralmente as respostas, o professor projetará a imagem da capa do livro O Homem Nu (Anexo 19) de Fernando Sabino, e fará a seguinte pergunta aos alunos, para que eles respondam oralmente. 


\section{O que vocês acham que é isto?}

Observação: Com este questionamento, o professor pretende que os alunos percebam tratar-se da capa do livro, onde se encontra o conto O Homem $\mathrm{Nu}$, que serviu para se criar a adaptação da obra cinematográfica a que eles assistiram nas aulas anteriores.

- Após o professor verificar oralmente as respostas dos alunos, informará a eles que será lido o conto $\mathrm{O} H o m e m ~ \mathrm{Nu}$, do autor belo-horizontino Fernando Sabino, nascido em 12 de outubro de 1923 e falecido em 11 de outubro de 2004, e que, além de ter sido escritor, foi jornalista e editor. O docente também elucidará que os textos de Fernando Sabino apresentam, como uma das características, a presença do humor. Após apresentar essa minibiografia do cronista, o professor explicará aos alunos que o conto serviu para criar a adaptação do filme a que eles assistiram nas aulas anteriores. Entretanto, antes de iniciar a leitura, o docente fará o seguinte questionamento aos alunos:

\section{Caros alunos, o que é mesmo adaptação?}

Observação: O professor deverá esperar que os alunos rememorem o conceito de adaptação, que já fora estudado anteriormente, consultando o próprio diário de leitura. Caso os discentes não consigam chegar a uma resposta, o professor retomará o conceito, projetando-o no quadro e novamente o esclarecendo (Anexo 20).

- Depois de rememorar o conceito de adaptação, por meio da resposta oral dos alunos, o professor entregará de forma individualizada um texto impresso do conto O Homem Nu (Anexo 21).

- Antes de começar a leitura, será explicado aos discentes que o texto será lido em voz alta e que a leitura será compartilhada, de modo que eles deverão se 
prontificar a lê-lo. O docente iniciará a leitura e depois solicitará aos alunos que prossigam a leitura do texto.

- Depois de realizada a leitura, o docente fará os seguintes questionamentos, para que os alunos os respondam oralmente.

Agora que acabamos de ler o texto, pergunto a vocês:

1- O texto que acabamos de ler pertence ao gênero textual "Conto". Vocês lembram o que é um conto?

Observação: O professor deverá esperar que os alunos rememorem o conceito de conto, que já fora estudado anteriormente, consultando o próprio diário de leitura. Caso os discentes não consigam chegar a uma resposta, o professor retomará o conceito, projetando-o no quadro e novamente o esclarecendo (Anexo 22).

2- Diferentemente dos outros contos que já lemos, esse texto possui uma autoria, ou seja, ele não foi compilado do acervo de histórias populares. Que informação comprova essa afirmativa no texto lido?

3- Quais os aspectos do conceito de conto, que estamos agora relembrando, aplicam-se a esse texto lido?

- Após o professor verificar as respostas oralmente dos alunos, solicitará que eles se organizem em equipes com quatro participantes, visando à interação do grupo sobre o conto e o filme. Cada equipe receberá uma ficha com atividades, conforme descrito no quadro seguinte. Eles terão um tempo para responderem às questões. 
Tendo por base a obra cinematográfica a que assistimos e o texto que acabamos de ler, respondam:

1- Qual é o nome da obra cinematográfica?

2- Qual é o nome do diretor que dirigiu o filme?

3- A que gênero cinematográfico se enquadra o filme? Por quê?

4- Qual é o título do texto?

5- Qual é o nome do escritor do texto?

6- A que gênero textual pertence o texto lido? Por quê?

7- Entre o filme e o texto existem muitas ou poucas diferenças?

8- Tendo por base as diferenças entre o filme e o conto, aponte-as conforme as seguintes categorias da narrativa:
a) Enredo:
b) Espaço:
c) Tempo:
d) Personagens:

- O professor ouvirá atentamente as respostas das equipes, de forma a verificar se os discentes conseguiram perceber as diferenças entre o texto lido e a obra filmica, tendo por base as categorias da narrativa que mais se destacam entre ambos os objetos de exploração. Também é importante que os alunos compreendam que assim como o texto é uma obra autêntica, o filme, embora 
seja uma adaptação do conto, também é uma obra original devido às características próprias. 


\section{Etapa 5: Atividade Avaliativa - "Quem conta um conto aumenta um ponto"}

O professor finalizará essa proposta de intervenção pedagógica com uma atividade de produção textual, que tem por intuito valorizar a herança cultural da comunidade dos discentes e tentar verificar se houve uma promoção de letramento literário e ampliação de repertório por meio das atividades desenvolvidas durante o processo. Essa etapa final ocorrerá em quatro momentos, conforme descrito a seguir.

\section{$1^{\circ}$ Momento}

Tempo: 1 aula/50 min

- O professor solicitará aos alunos que se organizem em duplas, advertindo que essa formação deverá permanecer a mesma para o segundo e o terceiro momentos.

- Em seguida, ele fará a apresentação da proposta, projetando na lousa uma imagem do filme contendo a reprodução da fala final (1h17min14s até 1h17min38s) da personagem que a atriz Marieta Severo interpreta como contadora de história na obra filmica Pequenas Histórias do diretor Helvécio Ratton.

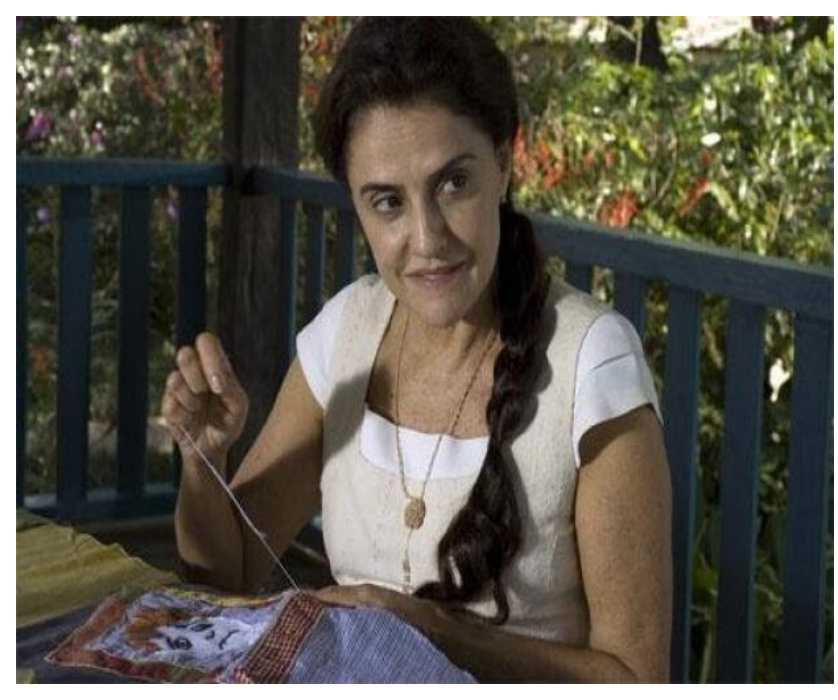

"E aqui acaba a nossa última história. Todos os pontos foram dados, os alinhavos costurados. Quem gostou, chama os outros para assistirem. Cada vez que eu conto um conto, eu dou mais um ponto. Será que, cada vez que eu conto um conto, eu aumento um ponto?"

- O docente fará a leitura da fala da personagem e dirá: 
$\boldsymbol{V}$ Chegamos ao final da nossa atividade interventiva. Durante 0 desenvolvimento da sequência pedagógica, experimentamos contos e obras filmicas que nos proporcionaram encontros significativos com a palavra, como meio de sonhar, contar e recontar as histórias. Assim, como a fala da personagem, que já é uma conhecida de nossas aulas, chegou o momento de alinhavar e costurar o que aprendemos.

$\checkmark$ A proposta é realmente dar mais um ponto ou, quem sabe, aumentar mais um ponto. Vocês, em dupla, deverão produzir um pequeno conto a partir de um "causo" que faça parte de sua comunidade. Com certeza, a comunidade de vocês possui muitas histórias que fazem parte do imaginário coletivo. Cada dupla deverá coletar um "causo" e deverá escrevê-lo em forma de conto, tendo em vista o que aprenderam sobre a estrutura do conto.

Observação: Nesse momento, o professor explicará aos estudantes que cada dupla deverá colher junto a seus familiares ou vizinhos um "causo" que achar mais interessante, pedindo a eles que os conte. Durante a narração do causo, os alunos deverão anotá-lo em seu diário de leitura. O docente também elucidará aos discentes que o texto coletado é apenas um rascunho, pois ele será explorado no próximo momento em sala de aula.

\section{$2^{\circ}$ Momento}

Tempo: 4 aulas $/ 50 \mathrm{~min}$

- O professor solicitará aos alunos que se organizem novamente em duplas, preferencialmente, a mesma do momento anterior. Cada dupla receberá duas folhas: uma, onde será feita a ilustração, e a outra para a escrita da produção final. 
- O professor explicará aos alunos o porquê de terem recebido duas folhas. $\mathrm{Na}$ primeira folha (Anexo 23), eles deverão realizar uma ilustração (que pode ser feita através de desenho ou de colagem) sobre o conto; na segunda folha (Anexo 24), eles deverão redigir a produção final do conto, a partir do "causo" coletado que eles anotaram no diário de leitura.

- Para esse momento, o professor também fará uma recuperação sobre o conceito de conto e suas características, como, também, de algumas categorias da narrativa, conforme descrito abaixo.

- O professor colocará as perguntas no quadro e fará a leitura em voz alta para os alunos. Após, os discentes deverão responder oralmente às perguntas. Todavia, deverão usar o próprio diário de leitura para pesquisar e formular as respostas. As perguntas têm como finalidade orientar as duplas na composição do texto.

Durante as nossas aulas, aprendemos alguns conceitos importantes. Antes de vocês começarem a explorar os "causos" e escrevê-los em forma de Conto", vamos relembrar alguns desses conteúdos que serão muito úteis para a produção de texto de vocês.

1- O que é conto?

2- Quais as características de um conto?

3- Que elementos narrativos não podem faltar na composição de um conto?

- Depois dessa breve retomada oral de conceitos, o docente também solicitará que as duplas iniciem a produção do conto. Entretanto, eles deverão, primeiramente, produzi-lo no diário de leitura, que será apenas um rascunho. Somente após a revisão feita pelo professor, as duplas deverão transcrever o texto produzido para a folha de produção final. 
- O professor informará também que o texto deverá ser escrito com letra legível, pois eles estarão escrevendo um texto que será lido por outras pessoas. Também, será pedido que as duplas coloquem um título no texto produzido.

- Enquanto os alunos estiverem produzindo, o professor deverá visitar as duplas para sanar dúvidas quanto às questões ortográficas e mesmo sobre a estrutura do conto.

- Após a produção, o professor solicitará que cada dupla leia em voz alta o texto produzido, para que as outras duplas também possam conhecer o conto.

- Após a leitura, o professor recolherá as duas folhas para serem utilizadas em um próximo momento.

\section{$3^{\circ}$ Momento}

Tempo: 4 aulas/50 min

- O professor solicitará que os alunos se organizem novamente em duplas, preferencialmente, a mesma do momento anterior.

- Cada dupla receberá uma produção que foi realizada por outra. Após, o professor entregará às duplas uma ficha impressa, conforme modelo constante na próxima página, e dará a orientação, explicando que as duplas deverão identificar as categorias da narrativa na produção que receberam. 
A partir do Conto que vocês receberam, identifique as seguintes informações:

1- Título:

2- Enredo:

Enredo:

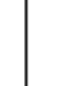

3- Personagens:

4- Tempo:

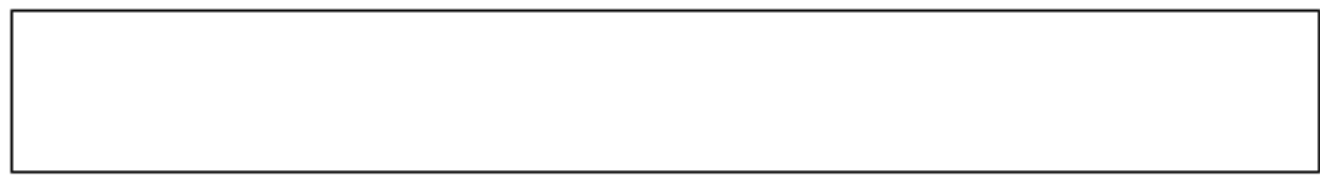

5- Espaço:

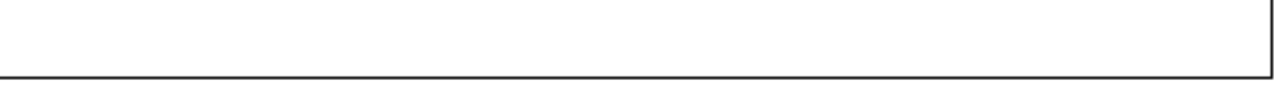

6- Narrador:

- Após a resolução da tarefa, o professor checará oralmente as respostas das duplas.

- Depois da correção, o professor realizará uma votação anônima, conforme orientação descrita abaixo, para escolher o melhor conto; entretanto, o aluno deverá justificar a escolha, tendo como parâmetro de justificativa os conteúdos aprendidos durante a proposta pedagógica. 
Agora que vocês já conhecem os contos produzidos pelos colegas, vocês receberão uma folha impressa (Anexo 25). Nessa folha, vocês não precisam se identificar, somente deverão colocar o título do conto de que mais gostaram e, além disso, deverão justificar a escolha a partir do conteúdo que aprenderam durante as nossas aulas.

Observação: Nessa tarefa de votação, para facilitar a escolha, o professor escreverá na lousa os títulos dos contos produzidos pelos grupos. Cada aluno receberá uma folha impressa, onde deverá indicar o título e a justificativa da escolha, sem se identificar. Após a escolha, cada discente colocará sua resposta dentro de uma caixa que o professor preparou para essa atividade. Após todos os alunos realizarem a votação, o professor abrirá a caixa diante dos alunos e iniciará a leitura dos votos, de forma que poderá pontuar os títulos escritos no quadro, assinalando a recorrência dos votos. No momento da contagem dos votos, o docente chamará os alunos individualmente para retirar da caixa um voto aleatoriamente e proceder à leitura do título e da justificativa. Depois de verificar o número dos votos, o grupo que elaborou o conto vencedor será premiado com um livro. A premiação da atividade levará em conta a faixa etária dos estudantes e será ofertado, preferencialmente, um livro de contos a cada aluno desse grupo. Os livros serão diversificados, a critério do professor.

\section{$4^{\circ}$ Momento}

Tempo: 1 aula/ $50 \mathrm{~min}$

- O professor montará um painel, preferencialmente, num lugar onde haja circulação de outras turmas, para apresentar as ilustrações e os contos produzidos pelos alunos do $9^{\circ}$. ano do Ensino Fundamental. 


\section{6- Referências Bibliográficas}

ALBISSÚ, Nelson. Contos de mistério \& assombros. 1. ed. Cortez Editora, 2012.

ARROYO, Leonardo. Literatura Infantil Brasileira. São Paulo: Unesp, 2011.

AZEVEDO, Ricardo. Histórias de bobos, bocós, burraldos e paspalhões. Porto Alegre: Editora Projeto, 2001.

BRASIL. Base Nacional Comum Curricular. Disponível em:<http://basenacionalcomum.mec.gov.br/images/BNCC EI EF_110518_versaofinal site.pdf>[online]. 600 p. 2018. Acesso em: 05 de out. de 2019.

Parâmetros Curriculares Nacionais: terceiro e quarto ciclos do ensino fundamental: Língua Portuguesa. Secretaria de Educação Fundamental. Brasilia: MEC/SEF. 1998.

BORTONI-RICARDO, Maris Stella. O professor pesquisador: introdução à pesquisa. São Paulo: Parábola Editora, 2008.

CANDIDO, Antônio. O direito à literatura. In: Vários escritos. 3. ed. São Paulo: Duas Cidades, 1995, p. 170 - 191.

COELHO, Nelly Novaes. Literatura infantil. Teoria, análise, didática. São Paulo: Moderna, 2000, p. 92-149.

CHARTIER, Roger. A ordem dos livros: leitores, autores e bibliotecas na Europa entre os séculos XIV e XVIII. Trad. Del Priore, Mary - Brasilia: Editora Universidade de Brasilia, 2. ed., 1998, p. 11-31.

COLOMER, Teresa. Andar entre livros: a leitura literária na escola. Trad. Laura Sandroni. São Paulo: Global, 2007.

COSSON, Rildo. Círculos de leitura e letramento literário. São Paulo: Contexto, 2014.

. Letramento Literário: teoria e prática. 2.ed. São Paulo: Contexto, 2016.

EVEN-ZOHAR, Itamar. O Sistema literário. In: Revista Translatio 4. Trad. MAROZO, Luís Fernando; CUNHA, Yanna Karla. Revisão Linguística: VAZQUES, Raquel Bello. 2013, p. 22-45.

GANCHO, Cândida Vilares. Como analisar narrativas. 7.ed. São Paulo: Ática, 2001.

HUTCHEON, Linda. Uma teoria da adaptação. 2. ed. Santa Catarina: Editora UFSC, 2013. 
ISER, Wolfgang. Campo de referência e seleção do repertório dos textos ficcionais. In: $\quad 0$ ato da leitura. Trad. KRESTSCHMER, Johannes. São Paulo: Editora 34, 1996, p. 128 - 157.

JUNIOR, Benjamin Abdala. Introdução à análise da narrativa. São Paulo: Scipione, 1995.

JOUVRE, Vicent. Por que estudar literatura? Tradutores Marcos Bagno e Marcos Marciolino. São Paulo: Parábola, 2012.

MACHADO, Ana Maria. Contos de fadas: de Perrault, Grimm, Andersen \& outros. Trad. BORGES, Maria Luiza X. de A. Rio de Janeiro: Zahar, 2010.

MOISÉS, Massaud. A criação literária: introdução à problemática da literatura. 3.ed. São Paulo: Edições Melhoramentos, 1970, p. 107-134.

O HOMEM NU. Gênero: Comédia. Produtora: IstoÉ. Direção de Hugo Carvana. (75min e 0 seg.). DVD, Resolução HD. Brasil, 1997.

PAIVA, Aparecida; PAULINO, Graça; PASSOS, Marta. Literatura e leitura na formação escolar: caderno do formador. Belo Horizonte: Ceale, 2006.

PAULINO, Graça; COSSON, Rildo. Letramento literário: para viver a literatura dentro e fora da escola. In: ZILBERMAN, Regina; ROSING, Tânia (Org). Escola e leitura: velhas crises, novas alternativas. São Paulo: Global, 2009, p. 61 - 79.

PELLEGRINI, Tânia et al. Literatura, cinema e televisão. São Paulo: Editora Senac São Paulo: Instituto Itaú Cultural, 2003.

PEQUENAS HISTÓRIAS. Comédia e Infantil. Direção: Helvécio Ratton. Brasil, 2007 (1h20min). Disponível em <http://tvines.org.br/?p=15991>Acesso em: 06 de mar. de 2020.

PREFEITURA DE MIGUEL PEREIRA. MIGUEL PEREIRA - Disponível em < http://www.pmmp.rj.gov.br/historia.php >Acesso em: 07 de mai. de 2019.

PROJETO POLÍTICO PEDAGÓGICO - PPP do C. E. Vera Cruz. Diretora: Jussara dos Santos. 2018.

SABINO, Fernando. Os melhores contos de Fernando Sabino. Rio de Janeiro: Record, 1986, p. 50-53.

SOARES, Magda. Letramento: um tema em três gêneros. 3.ed. Belo Horizonte: Autêntica Editora, 2009.

THIOLLENT, Michel. Metodologia da pesquisa-ação. 18.ed. São Paulo: Cortez, 2011.

VELHO, Gilberto. Individualismo e cultura. 7.ed. Rio de Janeiro: Jorge Zohar Editora, 2004, p.123-32. 
Anexo 1 - Motivação: Da tradição oral à compilação (págs. 13 e 14).

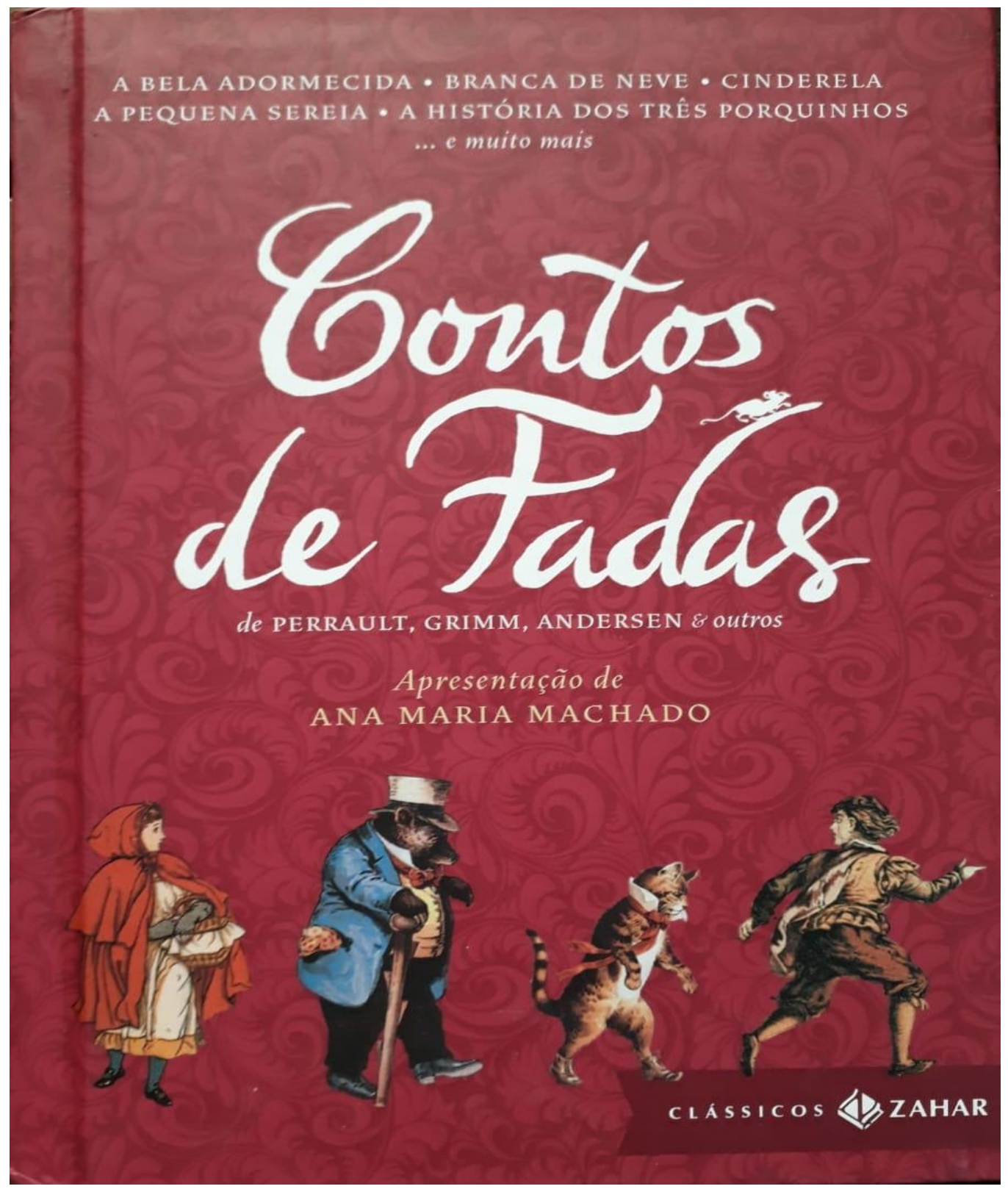


Anexo 2 - Motivação: Da tradição oral à compilação (pág. 14).

\section{Chapeuzinho Vennelho}

乌RA UMA vez uma pequena aldeã, a menina mais bonita que poderia haver. Sua mãe era louca por ela e a avó, mais ainda. Esta boa senhora mandou fazer para a menina um pequeno capuz vermelho. Ele lhe assentava tão bem que por toda parte aonde ia a chamavam Chapeuzinho Vermelho.

Um dia sua mãe, que assara uns bolinhos, lhe disse: "Vá visitar sua avó para ver

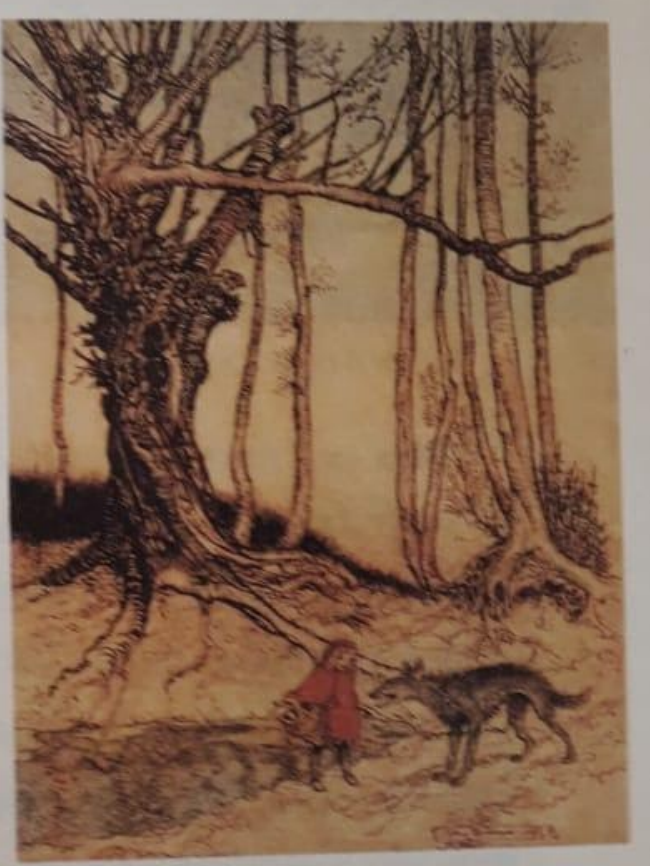

Arthur Rackham, 1909 como ela está passando, pois me disseram que está doente. Leve para ela um bolinho e este potinho de manteiga."

Chapeuzinho Vermelho partiu imediatamente para a casa da avó, que morava numa outra aldeia. Ao passar por um 


\section{Anexo 2 - Cont.,}

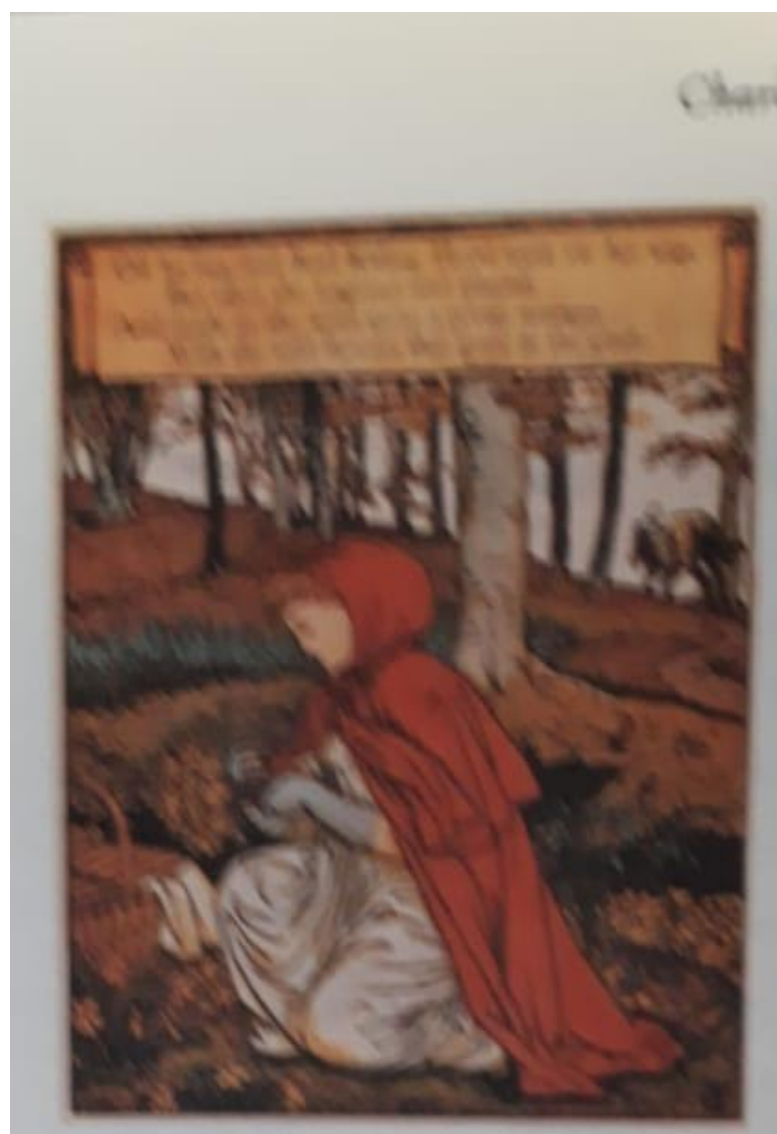

Walier Crane isy

boaque, encontrou o compedre laba que teve muita vontade de comề la, mas não se atrenec, por causa dos lenhadores que estavam na floresta. Ele the perguntou para onde ia. A pobre menina, que não sabia que era perigoso parar e dar ountdas a um loba respondec:

"Vou visitar minha avó e levar para ela um bolinho com um potìnho de manteiga que minha mãe estả mandanda"

"Sua avó mora muito longe?" perguntou o loba.

"Ah! Mora sim", respondeu Chapeuzinho Vermelha. "Mora depois daquele moìnho lá longe, bem longe, na pritmeira casa da aldeia."

"Otimol" disse o lobo, "Vou visìta-la também. Vou por este caminho aqui e vocè vaì por aquele caminho ali. E vamos ver quem chega prìmeino."

O lobo pós-se a correr o mais que podia pelo caminho mais curto, e a menina seguiu pelo caminho mais longa or tretendo-se em catar castanhas, correr atrais das borbolects e fazer buquès com as flores que encontrava. O lobo nio demorou muito para chegar à casa da avó. Bateu: Toc, toc, toc. 
Anexo 2 - Cont.,

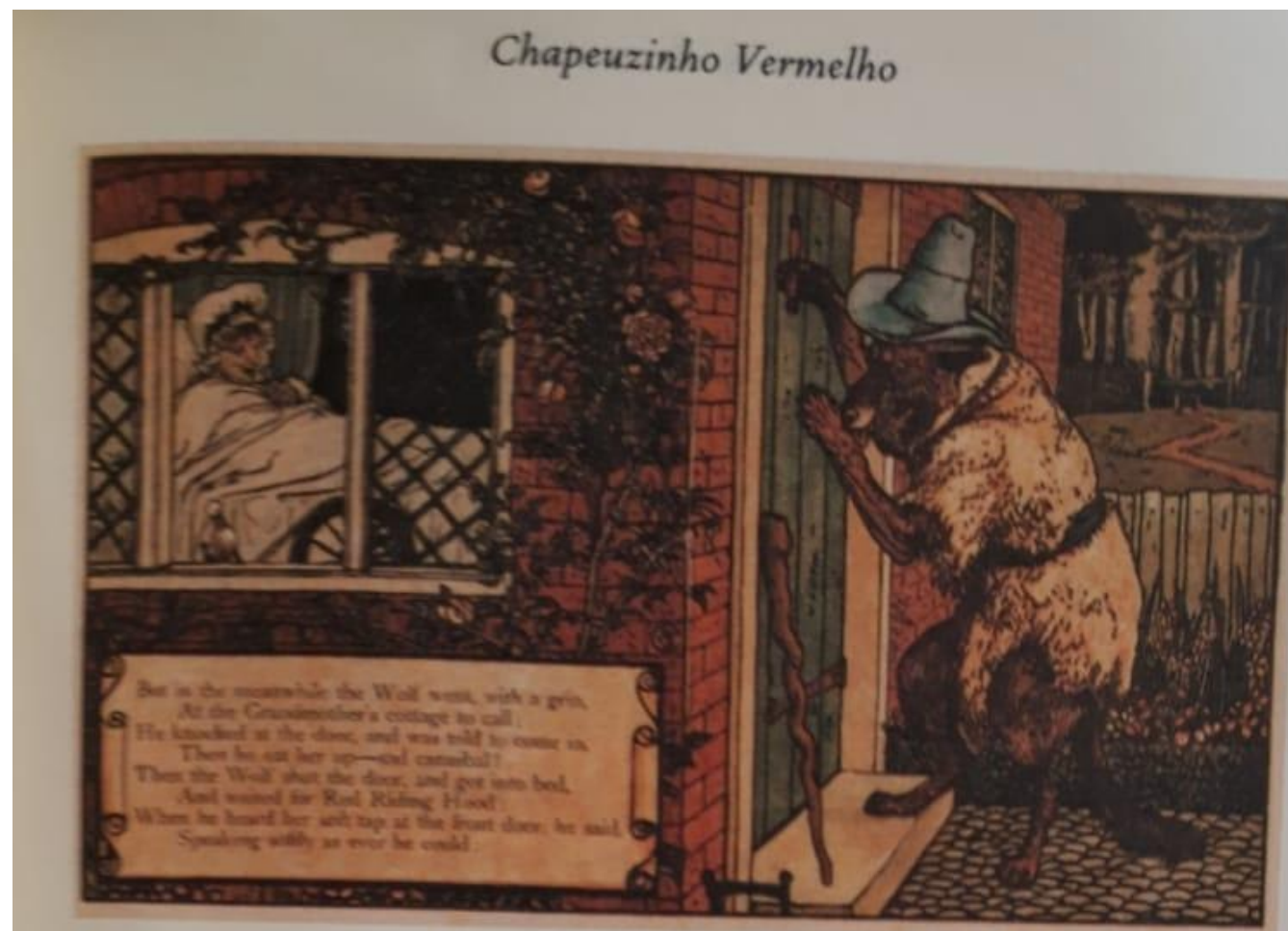

Gustave Doré, 1861

"Quem está aî?"

"É sua neta, Chapeuzinho Vermelho", disse o lobo, disfarçando a voz. "Estou trazendo um bolinho e um potinho de manteiga que minha mãe mandou."

A boa avó, que estava de cama por andar adoentada, gritou: "Puxe a lingueta e o ferrolho se abrirá."

O lobo puxou a lingueta e a porta se abriu. Jogou-se sobre a boa mulher e a devorou num piscar de olhos, pois fazia três dias que não comia. Depois fechou a porta e foi se deitar na cama da avó, à espera de Chapeuzinho Vermelho, que pouco tempo depois bateu à porta. Toc, toc, toc. 
Anexo 2 - Cont.,

\section{Charles Perrault}

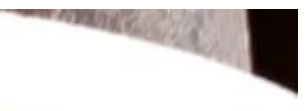

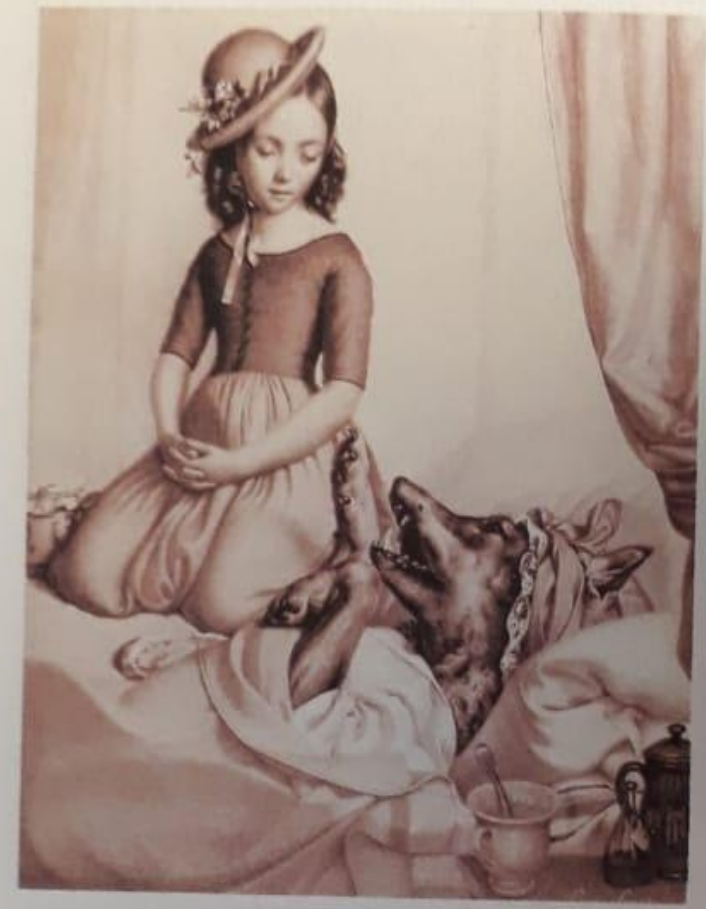

Eugéne Feyen, 1846
"Quem está aí?"

Ouvindo a voz grossa do lobo, Chapeuzinho Verme. lho primeiro teve medo, mas, pensando que a avó estava gripada, respondeu:

"É sua neta, Chapeuzinho Vermelho. Estou trazendo um bolinho e um potinho de manteiga que minha mãe mandou."

O lobo gritou de volta, adoçando um pouco a voz:

Chapeuzinho Vermelho puxou a lingueta e a porta se abriu. O lobo, vendo-a entrar, disse-lhe, escondendo-se na cama debaixo das cobertas:

"Ponha o bolo e o potinho de manteiga em cima da arca, e venha se deitar comigo."

Chapeuzinho Vermelho tirou a roupa e foi se enfiar na cama, onde ficou muito espantada ao ver a figura da avó na camisola. Disse a ela:

"Minha avó, que braços grandes você tem!" "É para abraçar você melhor, minha neta." "Minha avó, que pernas grandes você tem!" 


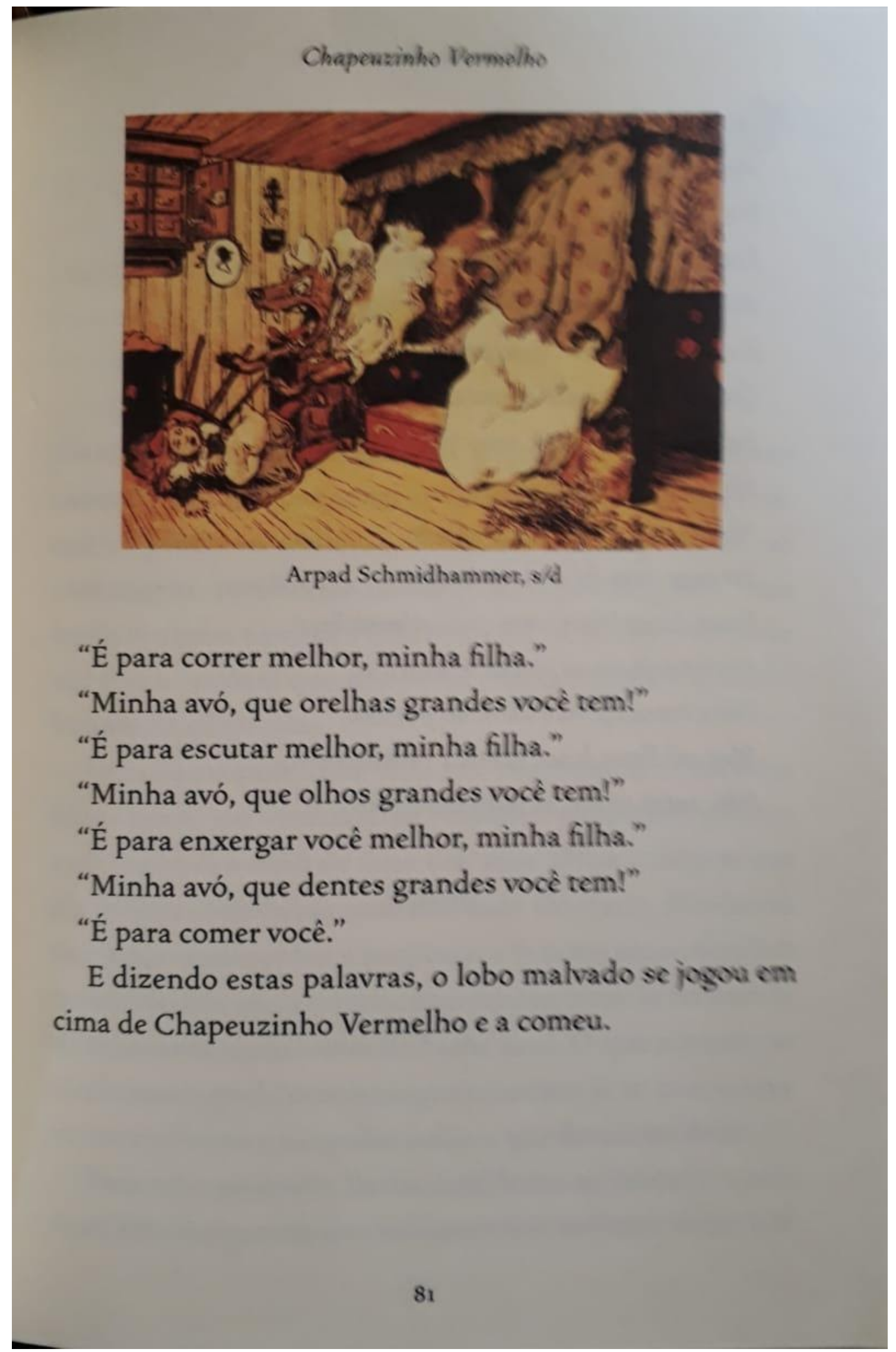


Anexo 2 - Cont.,

\section{Charles Perrault}

\section{D(gral}

Vemos aqui que as meninas,

E sobretudo as mocinhas

Lindas, elegantes e finas,

Não devem a qualquer um escutar.

E se of fazem, não é surpresa

Que do lobo virem o jantar.

Falo "do" lobo, pois nem todos eles

São de fato equiparáveis.

Alguns são até muito amáveis,

Serenos, sem fel nem irritação.

Esses doces lobos, com toda educação,

Acompanham as jovens senhoritas

Pelos becos afora e além do portão.

Mas ai! Esses lobos gentis e prestimosos,

São, entre todos, os mais perigosos.

MACHADO, Ana Maria. Contos de fadas: de Perrault, Grimm, Andersen \& outros. Trad. BORGES, Maria Luiza X. de A. Rio de Janeiro: Zahar, 2010, p. 77 a 82. 
Anexo 3 - Motivação: Da tradição oral à compilação (pág. 14).

\section{Crapeuzinho Venmelho}

Gra uMa vez uma menininha encantadora. Todos que batiam os olhos nela a adoravam. $E$, entre todos, quem mais a amava era sua avó, que estava sempre lhe dando presentes. Certa ocasião ganhou dela um pequeno capuz de veludo vermelho. Assentava-lhe tão bem que a menina queria usá-lo o tempo todo, e por isso passou a ser chamada Chapeuzinho Vermelho.

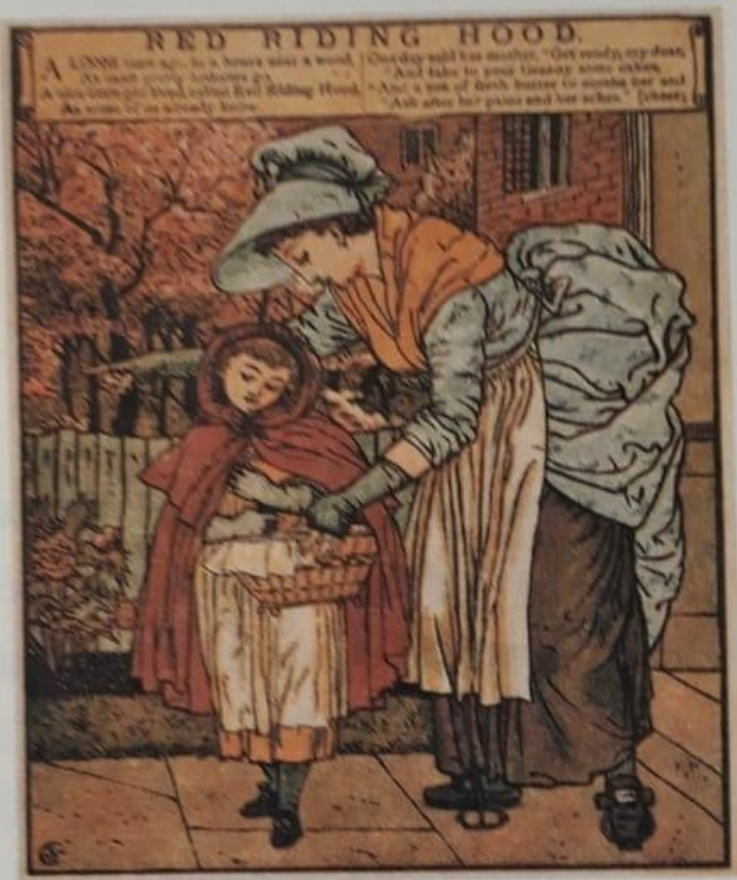

Walter Crane, 1875

Um dia, a mãe da menina lhe disse: "Chapeuzinho Vermelho, aqui estão alguns bolinhos e uma garrafa de vinho. Leve-os para sua avó. Ela está doente, sentindo-se fraquinha, e estas coisas vão revigorá-la. Trate de sair agora mesmo, antes que o sol fique quente demais, e quando estiver na floresta 


\section{Anexo 3 - Cont.,}

\section{Jacob e Wilholm Grimm}

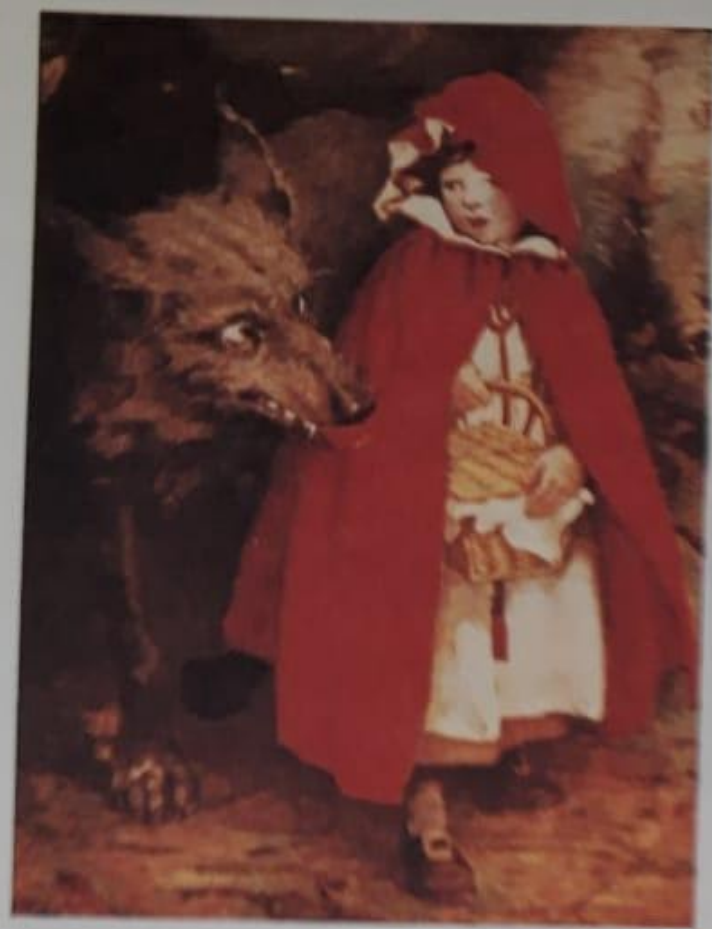

Jessie Willcox Smith, 1919

olhe para a frente como bua boa menina e nâo se dewie do caminho. Senäo, pode cair e quebrar a garrafa, e näo sobratá nada para a awó. E quado entrar, nāo se esquega de dizer bom dia e não Gque bisbillotando pelos cantos da casa"

"Farei tudo o que está dizendo", Chapecuinho Vermelho prosmeteu à mẫ.

Sua awó morexa la no meio da mata, a mais co menos uma hora de caminhada da aldcia. Mal pisara ma floresta, Char peuzinho Vermelho topou com o loba. Como zầ tinhta a menor ideia do animal makrado que ele era, nẫo texe um pingo de medo.

"Bom dia, Chapeuzinho Vermelho", disse o lato.

"Bom dia, senhor Lobo", ela respondece.

"Aonde está indo tà̀o cedo de manhả, Chapeuzinho ver melho?"

"À casa da vovó,"

"O que é isso debaiko do seu avental?"

"Uns bolinhos e uma garaafa de winho Ascamos oncem e a vovó, que está doente e fraçuinha. precica de alguma 


\section{Chapeuzinho Vermelho}

coisa para animá-la", ela respondeu.

"Onde fica a casa da sua vovó, Chapeuzinho?"

"Fica a um bom quarto de hora de caminhada mata adentro, bem debaixo dos três carvalhos grandes. O senhor deve saber onde é pelas aveleiras que crescem em volta", disse Chapeuzinho Vermelho.

O lobo pensou com seus botões: "Esta coisinha nova

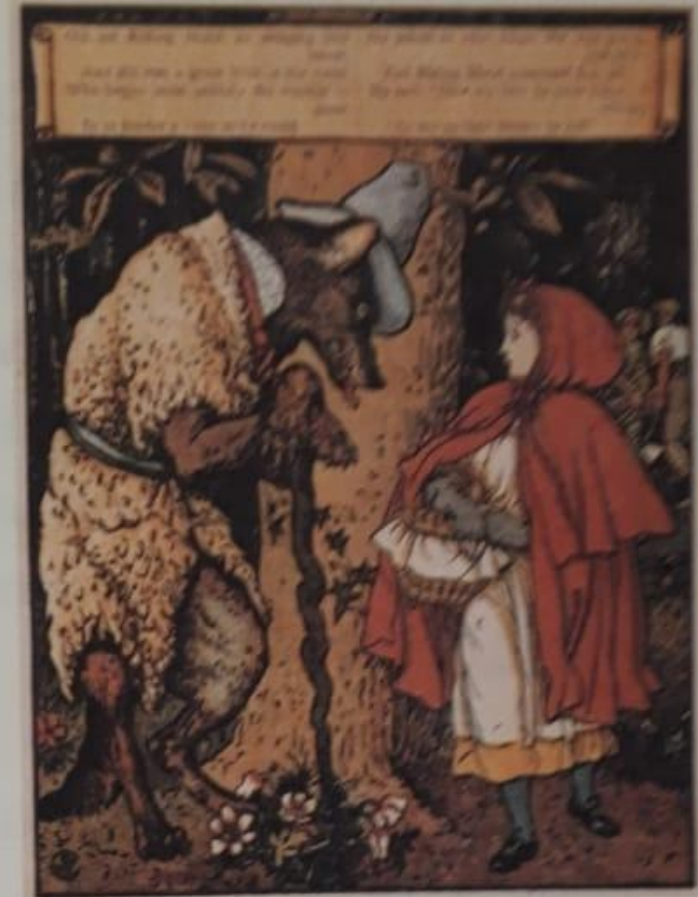

Walter Crane, 1875 e tenra vai dar um petisco e tanto! Vai ser ainda mais suculenta que a velha. Se tu fores realmente matreiro, vais papar as duas."

O lobo caminhou ao lado de Chapeuzinho Vermelho por algum tempo. Depois disse: "Chapeuzinho, notou que há lindas flores por toda parte? Por que não para e olha um pouco para elas? Acho que nem ouviu como os passarinhos estão cantando lindamente. Está se comportando como se estivesse indo para a escola, quando é tudo tão divertido aqui no bosque."

Chapeuzinho Vermelho abriu bem os olhos e notou como os raios de sol dançavam nas árvores. Viu flores bo- 


\section{Jacob e Wilhelm Grimm}

nitas por todos os cantos e pensou: "Se eu levar um buquê fresquinho, a vovó ficará radiante. Ainda é cedo, tenho tempo de sobra para chegar lá, com certeza."

Chapeuzinho Vermelho deixou a trilha e correu para dentro do bosque à procura de flores. Mal colhia uma aqui, avistava outra ainda mais bonita acolá, e ia atrás dela. Assim, foi se embrenhando cada vez mais na mata.

O lobo correu direto para a casa da avó de Chapeuzinho e bateu à porta.

"Quem é?"

"Chapeuzinho Vermelho. Trouxe uns bolinhos e vinho. Abra a porta."

"É só levantar o ferrolho", gritou a avó. "Estou fraca demais para sair da cama."

O lobo levantou of ferrolho e a porta se escancarou. Sem dizer uma palavra, foi direto até a cama da avó e a devorou inteirinha. Depois, vestiu as roupas dela, enfiou sua touca na cabeça, deitou-se na cama e puxou as cortinas.

Enquanto isso Chapeuzinho Vermelho corria de um lado para outro à cata de flores. Quando tinha tantas nos braços que não podia carregar mais, lembrou-se de repente de sua avó e voltou para a trilha que levava à casa dela. Ficou surpresa ao encontrar a porta aberta e, ao entrar na casa, teve uma sensação tão estranha que pensou: "Puxa!
Sempre me sinto tão alegre quando estou na casa da vovó, 


\section{Chapeuzinho Vermelho}

mas hoje estou me sentindo muito aflita."

Chapeuzinho Vermelho gritou um olá, mas não houve resposta. Foi então até a cama e abriu as cortinas. Lá estava sua avó, deitada, com a touca puxada para cima do rosto. Parecia muito esquisita.

"Ó avó, que orelhas grandes você tem!"

"É para melhor te escutar!"

"Ó avó, que olhos grandes

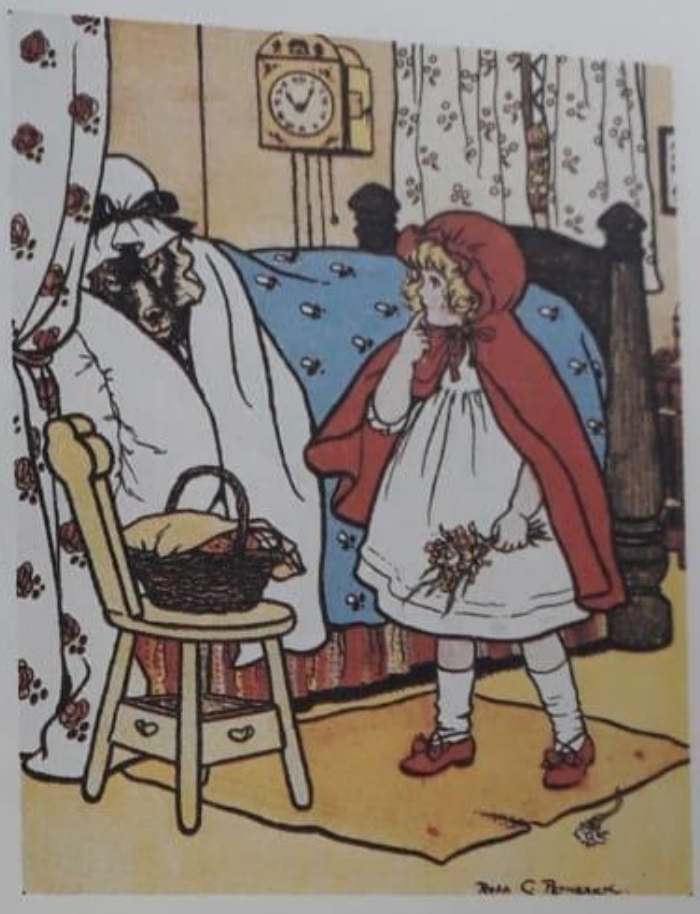

Rosa Petherick, s/d você tem!"

"É para melhor te enxergar!"

"Ó avó, que mãos grandes você tem!"

"É para melhor te agarrar!"

"Ó avó, que boca grande, assustadora, você tem!"

"É para melhor te comer!"

Assim que pronunciou estas últimas palavras, o lobo saltou fora da cama e devorou a coitada da Chapeuzinho Vermelho.

Saciado o seu apetite, o lobo deitou-se de costas na cama, adormeceu e começou a roncar muito alto. Um caçador que por acaso ia passando junto à casa pensou: "Como essa velha está roncando alto! Melhor ir ver se há algum pro- 


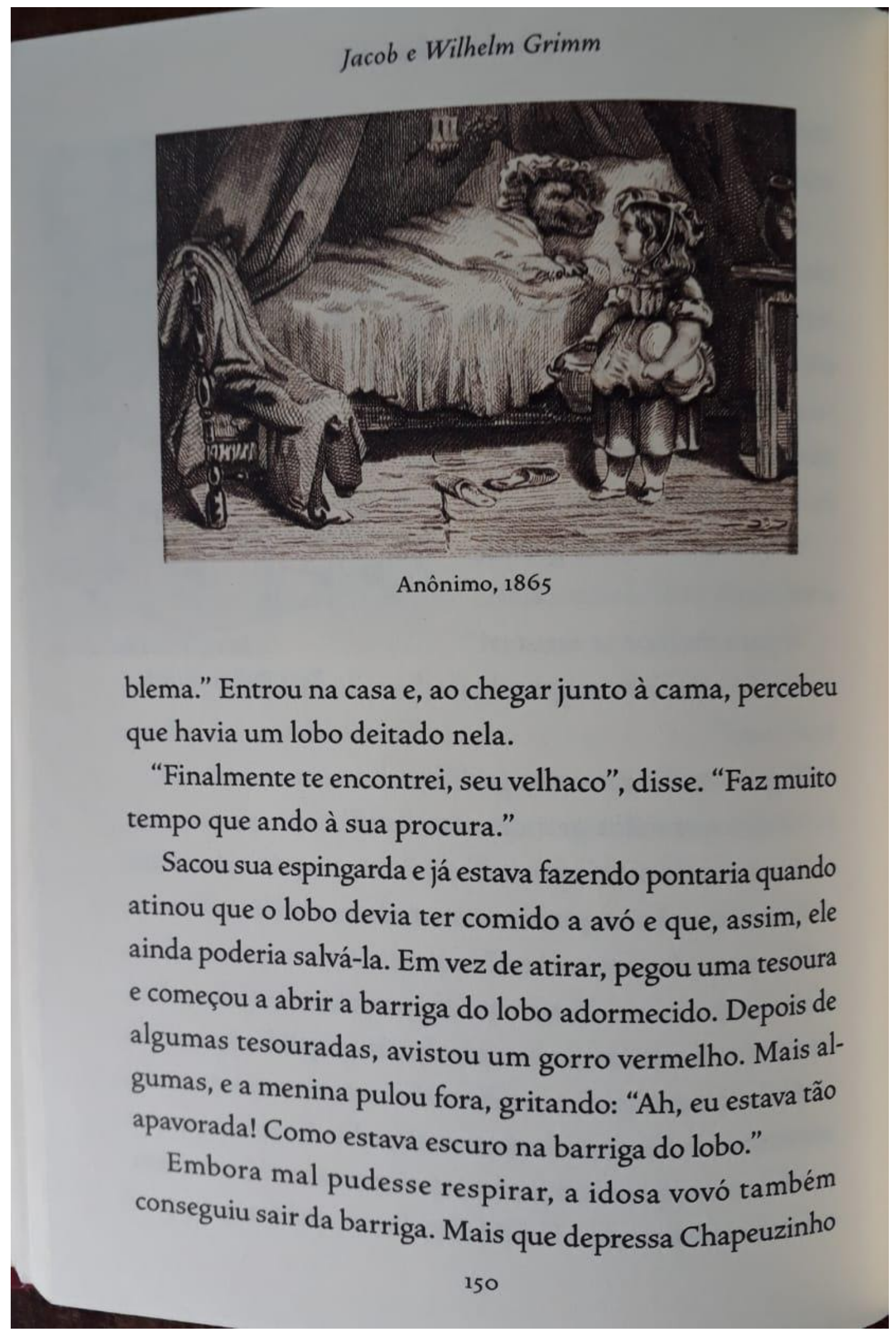




\section{Chapeuzinho Vermelho}

Vermelho catou umas pedras grandes e encheu a barriga do lobo com elas. Quando acordou, o lobo tentou sair correndo, mas as pedras eram tão pesadas que suas pernas bambearam e ele caiu morto.

Chapeuzinho Vermelho, sua avó e o caçador ficaram radiantes. $\mathrm{O}$ caçador esfolou o lobo e levou a pele para casa. A avó comeu os bolinhos, tomou o vinho que a neta lhe

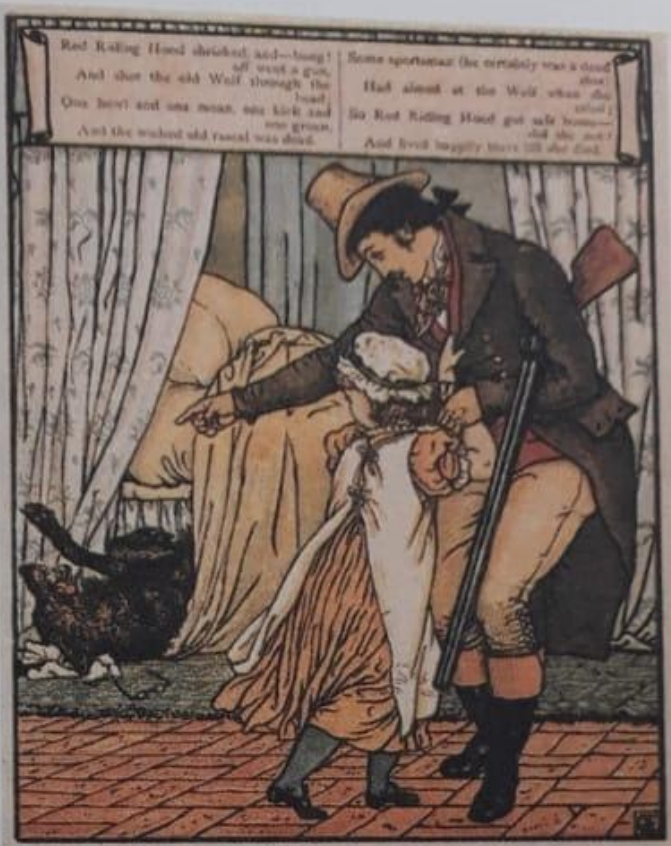

Walter Crane, 1875 levara, e recuperou a saúde. Chapeuzinho Vermelho disse consigo: "Nunca se desvie do caminho e nunca entre na mata quando sua mãe proibir."

HÁ UMA HISTÓRIA sobre uma outra vez em que Chapeuzinho Vermelho encontrou um lobo quando ia para a casa da avó, levando-lhe uns bolinhos. O lobo tentou fazê-la desviar-se da trilha, mas Chapeuzinho Vermelho estava alerta e seguiu em frente. Contou à avó que encontrara um lobo e que ele a cumprimentara. Mas tinha olhado para ela de um jeito tão mau que "se não estivéssemos num descampado, teria me devorado inteira". 


\section{Jacob e Wilhelm Grimm}

"Pois bem", disse a avó. "Basta trancar a porta e ele não poderá entrar."

Alguns instantes depois o lobo bateu à porta e gritou: "Abra a porta, vovó. É Chapeuzinho Vermelho, vim lhe trazer uns bolinhos."

As duas não abriram a boca e se recusaram a atender a porta. Então o espertalhão rodeou a casa algumas vezes e pulou para cima do telhado. Estava planejando esperar até que Chapeuzinho Vermelho fosse para casa. Pretendia rastejar atrás dela e devorá-la na escuridão. Mas a avó descobriu suas intenções. Havia um grande cocho de pedra na frente da casa. A avó disse à menina: "Pegue este balde, Chapeuzinho Vermelho. Ontem cozinhei umas salsichas. Jogue a água da fervura no cocho."

Chapeuzinho Vermelho levou vários baldes d'água ao cocho, até deixá-lo completamente cheio. O cheiro daquelas salsichas chegou até as narinas do lobo. Ele esticou tanto o pescoço para farejar e olhar em volta que perdeu 0 equilíbrio e começou a escorregar telhado abaixo. Caiu bem dentro do cocho e se afogou. Chapeuzinho Vermelho voltou para casa alegremente e ninguém lhe fez mal algum.

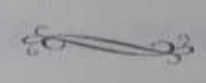

152

MACHADO, Ana Maria. Contos de fadas: de Perrault, Grimm, Andersen \& outros. Trad. BORGES, Maria Luiza X. de A. Rio de Janeiro: Zahar, 2010, p. 145 a 152. 
Anexo 4 - Etapa 1: Do acervo popular à adaptação (pág. 19).

\section{FAÇANHAS DO ZÉ BURRALDO}

Zé Burraldo era boa pessoa, mas burro feito uma porta.

Um dia, seu pai ficou doente.

- Filho - chamou o velho, deitado na cama. - Só tenho essa casa, um pouco de dinheiro e um burro. Deixo tudo pra você. E disse mais: - Preste atenção e ouça meu último conselho: saia pelo mundo pra ver se consegue dar um jeito na vida.

Disse isso, fechou os olhos e morreu. Mas antes, abriu os olhos e acrescentou:

- Cuidado pra não fazer muita besteira!

Ai, morreu mesmo.

Cheio de tristeza, Zé Burraldo achou melhor seguir os conselhos do pai. Guardou o dinheiro no bolso, passou uma corda no pescoço do burro e partiu, largando a casa trancada com as janelas abertas.

Andou, andou e andou tanto, que acabou ficando com sede. Por sorte, encontrou um poço no meio do caminho. Amarrando a corda numa folha de bananeira caída no chão, jogou a outra ponta dentro do poço e desceu. Como a folha de bananeira não aguentou o peso, Zé Burraldo foi parar estatelado no fundo do poço que, ainda por cima, não tinha uma gota d'água.

Tentando dar um jeito de escapar, o moço teve uma lembrança.

- Meu pai dizia que a Terra é redonda - pensou ele no escuro. - Então, se eu for cavando, acabo chegando do outro lado do mundo.

Pensou isso e começou a cavucar.

Passando pela estrada, um viajante escutou barulho no poço e parou. Ao descobrir que havia uma pessoa presa lá dentro, gritou:

- Calma, ai! - e jogou uma corda das grossas.

A ponta da corda tinha um nó e o nó bateu bem na testa do Zé Burraldo, que não gostou nem um pouco.

- Quer fazer o favor de parar com isso! - reclamou ele lá do fundo. - Não vê que está me atrapalhando? 
Anexo 4 - Cont.,

E o outro:

- Segure a ponta da corda!

E Zé Burraldo:

- Me deixe em paz que eu estou cavando!

O viajante insistiu e Zé Burraldo perdeu a paciência. Xingou o sujeito de tudo quanto foi nome. Diante disso, o viajante puxou a corda de volta, balançou os ombros e foi embora.

Por sorte, naquela tarde, caiu um temporal tão forte, tão forte, que encheu o poço e, desse jeito, boiando n'água, Zé Burraldo conseguiu escapar.

Continuou sua viagem, todo molhado, puxando o burro pela corda.

Dois malandros descansavam debaixo de uma árvore. Viram o moço passar e resolveram dar um golpe.

Chegando por trás, um deles conseguiu soltar o burro, sem que Zé Burraldo percebesse. Depois, rápido, deixou o bicho com o colega, amarrou a corda no pescoço e seguiu, amarrado, como se fosse o próprio burro.

Ao olhar para trás, Zé Burraldo levou um susto.

- Ô, burro! O que fizeram com você?

E o malandro:

- Mil vezes obrigado! Antigamente eu era um rapaz normal, mas, um dia, uma feiticeira me transformou num burro. Agora, graças a você -e ai o bandido caiu de joelhos chorando -, meu encanto foi quebrado!

Mesmo confuso, Zé Burraldo ajudou o sujeito a retirar a corda do pescoço.

- Livre! - gritava o falso ex-burro saltando e dando coices e relinchos de fingida alegria.

Depois, agarrou Zé Burraldo, beijou suas bochechas, agradeceu outra vez e partiu todo risonho.

Triste por ter perdido o burro, mas satisfeito por ter libertado o rapaz, Zé Burraldo continuou viagem puxando a corda vazia.

Perto da cidade, encontrou, por acaso, os bandidos de novo. Os dois levaram o burro para vender na cidade. 
Anexo 4 - Cont.,

Ao dar com Zé Burraldo, não perderam a calma.

- Lembra de mim? - perguntou o que tinha se fingido de burro. - Fui seu burro!

Zé Burraldo ficou feliz com o reencontro. Conversou um pouco, matou as saudades, examinou o burro dos malandros e estranhou.

- Mas é quase igualzinho ao meu!

- Igualzinho coisa nenhuma! - exclamou o outro bandido. - Este animal é diferente de todos os outros. É um caso raro! - e em voz baixa: - Ele é mágico!

Fragmento do texto "Façanhas do Zé Burraldo". AZEVEDO, R. História de bobos, bocós, burraldos e paspalhões. 1.ed. São Paulo: Ática, 2009. 
Anexo 5 - Etapa 1: Do acervo popular à adaptação (pág. 20).

Perto da cidade, encontrou, por acaso, os bandidos de novo. Os dois levaram o burro para vender na cidade.

Ao dar com Zé Burraldo, não perderam a calma.

- Lembra de mim? - perguntou o que tinha se fingido de burro. - Fui seu burro!

Zé Burraldo ficou feliz com o reencontro. Conversou um pouco, matou as saudades, examinou o burro dos malandros e estranhou.

- Mas é quase igualzinho ao meu!

- Igualzinho coisa nenhuma! - exclamou o outro bandido. - Este animal é diferente de todos os outros. É um caso raro! - e em voz baixa: - Ele é mágico!

Os dois mandaram Zé Burraldo colocar o chapéu debaixo do rabo do burro.

Daí a pouco, o animal resolveu fazer suas necessidades. Levantou o rabo, fez força e - cataploft - encheu o chapéu do moço de porcaria.

Zé Burraldo arregalou os olhos. No meio da " brilharam várias moedas.

É que os bandidos tinham enfiado dinheiro no rabo do burro.

- Não é que o burro é mágico mesmo! - exclamou Zé Burraldo encantado.

- Resolvi fazer uma coisa! - anunciou o falso ex-burro com voz solene. - Você me livrou daquela triste vida de burro de carga, por isso faço esse favor especial: vendo o bichinho pra você.

O outro malandro fez cara de susto:

- Isso é loucura! Não faça uma coisa dessas! Este burro é mágico! Este burro vale ouro!

Mas o primeiro insistiu.

- Ele merece! Salvou minha vida! E a vida - completou ele com voz filosófica vale mais que trezentos e trinta e três burros mágicos!

Achando que estava fazendo um ótimo negócio, Zé Burraldo enfiou a mão no bolso e deu todo dinheiro que tinha em troca do animal.

Os dois malandros abraçaram o burro, despediram-se emocionados, abraçaram o burro de novo e, sorridentes, sumiram na poeira amarela da estrada. 
Anexo 5 - Cont.,

Zé Burraldo seguiu seu caminho puxando o burro que um dia já tinha sido seu.

Chegou à cidade morrendo de fome. Lembrando-se que não tinha mais dinheiro, decidiu vender o burro. Foi até a praça e começou a gritar:

- Quem quer comprar um burro mágico?

O povo foi chegando curioso.

- Burro mágico?

Zé Burraldo explicou que aquele animal em vez de coco fazia moedas.

- Este animal é diferente de todos os outros! - dizia ele imitando a fala dos bandidos. - É um caso raro! - e em voz baixa: - Ele é mágico!

Ninguém queria acreditar.

Zé Burraldo tinha certeza do que estava falando. O povo ria. O moço insistia.

- Este burro é mágico! Este burro vale ouro!

- Então mostre! - desafiou um menino.

- É pra já! - respondeu Zé Burraldo, colocando, de novo, o chapéu debaixo do rabo do bicho.

Daí a pouco, o burro sentiu vontade de novo, levantou o rabo, suspirou fundo e - cataploft - encheu o chapéu do moço de tudo, menos dinheiro.

O povo gargalhava ao ver o moço, com mão enfiada na gosma, tentando pescar alguma moeda.

No fim, Zé Burraldo perdeu a paciência. Agarrou um pedaço de pau e começou a bater no burro.

- Estrumeiro, esterqueiro, lambuzeiro, mondongueiro! - berrava ele.

E explicava à plateia:

- O bicho tá segurando o dinheiro no bucho de propósito!

O povo chorava de rir.

Um diretor de teatro, passando por perto, assistiu à cena. Sua peça ia estrear aquela noite e um dos atores tinha ficado doente. Achou que Zé Burraldo era um grande artista e fez o convite. Queria que o rapaz substituísse o ator adoentado. 
Anexo 5 - Cont.,

- Vai ser fácil - disse o diretor.

Zé Burraldo aceitou porque precisava de dinheiro.

A noite chegou. O teatro encheu de gente. O papel de Zé era simples. Entrava em cena no terceiro ato e dizia: - "Eu sou o médico!"

- Só isso? - perguntou Zé Burraldo.

- Só isso - respondeu o diretor.

- Vai ser moleza! - pensou o moço atrás do palco, maquiado e fantasiado de médico, treinando em voz baixa para não esquecer: - "Eu sou o médico!"

Fragmento do texto "Façanhas do Zé Burraldo". AZEVEDO, R. História de bobos, bocós, burraldos e paspalhōes. 1.ed. São Paulo: Ática, 2009. 
Anexo 6 - Etapa 1: Do acervo popular à adaptação (pág. 23).

A noite chegou. 0 teatro encheu de gente. 0 papel de Zé era simples. Entrava em cena no terceiro ato e dizia: - "Eu sou o médico!"

- Só isso? - perguntou Zé Burraldo.

- Só isso - respondeu o diretor.

- Vai ser moleza! - pensou o moço atrás do palco, maquiado e fantasiado de médico, treinando em voz baixa para não esquecer: - "Eu sou o médico!"

O espetáculo começou.

Por um buraco no cenário, Zé Burraldo acompanhava as cenas.

No primeiro ato, uma moça linda - a mais linda que Zé Burraldo já tinha visto apareceu namorando e beijando um rapaz, o galã da história.

Zé Burraldo ficou apaixonado pela moça. Sentiu vontade de entrar no palco e dar uns beijinhos também.

- Deixa eu entrar só um pouco?

O diretor não deixou.

No segundo ato, aconteceu uma luta terrível. Bandidos com espada na mão atacaram o galã da história, que ficou no chão, gemendo e sangrando, morre não morre.

Atrás do palco, Zé Burraldo espiava aflito, pedindo para entrar.

- Mas eu sou médico! - repetia ele baixinho, tentando forçar a passagem. - 0 coitado ficou todo machucado!

$\mathrm{O}$ diretor não deixou.

Finalmente, veio o terceiro ato.

- É agora - mandou o diretor. - Entre!

Vestido de médico, Zé Burraldo apareceu confiante no palco.

A moça linda estava deitada na cama, pálida e imóvel. A seu lado, um homem e uma mulher choravam.

- Eu sou o médico! - exclamou Zé Burraldo com voz vitoriosa.

- Tarde demais - disse o homem chorando. 
Anexo 6 - Cont.,

- Tarde demais - disse a mulher soluçando.

- Como assim? - perguntou o moço.

O diretor, atrás da cortina, arregalou os olhos. Aquele "como assim?" não fazia parte do texto da peça.

- Nossa filha morreu! - explicou a mulher, ao lado da cama, tentando improvisar.

Zé Burraldo explodiu.

- A culpa é do diretor! Assassino desgramado! Desde o primeiro ato estou tentando entrar e ele não deixa! Agora, olha só o que aconteceu!

E, furioso, começou a puxar as cortinas, a derrubar e destruir tudo.

A confusão foi geral.

Assustada, a atriz pulou da cama e saiu correndo.

- Milagre! - gritou Zé Burraldo, caindo de joelhos ao ver a moça passar.

O público ria às gargalhadas.

Os atores não sabiam se ficavam ou se sumiam do palco.

O diretor já ia mandando chamar a polícia, mas mudou de ideia ao perceber que a plateia estava aplaudindo de pé. A verdade é que todo mundo adorou aquele final inesperado. Nunca antes aquela peça tinha feito tanto sucesso.

Zé Burraldo recebeu até convite para continuar trabalhando no grupo, mas não aceitou. Confessou que tinha medo de contracenar com gente que conseguia morrer e ressuscitar.

Ao se despedir, o diretor deu mais dinheiro do que o combinado. Contou que tinha tomado uma decisão: a partir daquela apresentação, o final da peça passaria a ser aquele.

Zé Burraldo não entendeu nada, guardou o dinheiro no bolso, pegou o burro e continuou a viagem.

Fragmento do texto "Façanhas do Zé Burraldo". AZEVEDO, R. História de bobos, bocós, burraldos e paspalhōes. 1,ed. Sāo Paulo: Ática, 2009. 
Anexo 7 - Etapa 1: Do acervo popular à adaptação (pág. 25).

No outro dia, encontrou uma goiabeira carregadinha na beira da estrada. Como estava com fome, amarrou o burro, trepou na árvore e teve uma ideia. Arranjou um serrote e resolveu serrar o galho, sentado no próprio galho.

Já estava terminando o trabalho quando passou um homem a cavalo. 0 sujeito ficou assustado:

- Cuidado, aí! Assim você cai e se machuca!

Disse isso e foi embora.

Logo depois, o galho rachou e Zé Burraldo foi parar no chão.

Levantou-se impressionado.

- Aquele sujeito é adivinho!

Montou no burro e saiu correndo atrás do cavaleiro. Galopava e gritava:

- Por favor, seu adivinho, espere aí!

0 outro parou o cavalo dizendo que não era adivinho coisa nenhuma.

Zé Burraldo sorriu e disse:

- Não seja modesto, senhor. É adivinho sim e dos bons. Agora mesmo adivinhou que eu ia cair da árvore e não deu outra!

$E$ aí, fez um pedido.

- Queria que o senhor adivinhasse uma coisa!

0 outro perguntou o que era.

- Quero saber o dia exato da minha morte!

0 cavaleiro resolveu fazer uma brincadeira. Respondeu que quando Zé

Burraldo puxasse 0 rabo de um burro e 0 bicho soltasse três puns, este seria 0 anúncio de sua morte.

- Mas precisam ser exatamente três - explicou o homem, escondendo o riso. 
Anexo 7 - Cont.,

- Não vale nem dois, nem quatro, nem mais, nem menos.

Disse isso, despediu-se e saiu galopando.

A partir daquele dia, Zé Burraldo voltou para casa e continuou sua vidinha de sempre. Com uma diferença. Puxava o rabo de todos os burros que encontrava pela frente.

Puxou mais de quatrocentos e tantos rabos de burros.

Chegou a levar vários coices, mordidas e pisadas, mas não desanimou.

Um dia, lembrou-se do próprio burro. O animal estava amarrado numa cerca, comendo capim.

- Será ele? - pensou Zé Burraldo emocionado. E foi correndo puxar o rabo do bicho, que, de barriga estufada, suspirou, caprichou, fechou os olhos e soltou três sonoros e afinados puns.

Zé Burraldo recuou. Sentiu que sua hora tinha chegado. Gritou gemendo:

- Gente que nunca morreu tá morrendo!

Um menino que passava perto, examinou o corpo e foi correndo avisar:

- Gente! O Zé Burraldo morreu!

Os vizinhos chegaram logo.

- Coitado! - disse uma senhora enxugando as lágrimas.

- Até que o Zé era boa gente - comentou um outro. - E nem era tão burraldo assim.

- Só um pouco - disse alguém.

- Mas como aconteceu?

- Deve ter levado um coice do burro! - explicou o menino.

Várias pessoas vieram ver o triste defunto.

O jeito era levar o corpo para o cemitério, que ficava longe, no alto da serra. 
Anexo 7 - Cont.,

Zé Burraldo foi colocado num caixão recheado de flores, e o cortejo fúnebre partiu. $\mathrm{O}$ sol estava de rachar. $\mathrm{O}$ padre seguiu na frente suando e rezando Pais-Nossos e Ave-Marias. Depois de andar muito, a procissão chegou a uma encruzilhada.

Parte do grupo queria seguir em frente. Outros achavam melhor pegar um atalho pela direita.

A discussão começou.

- Pelo atalho é menos ladeira.

- Mas é muito mais comprido.

- Pela direita é melhor.

- Não é.

- É!

Diante da dúvida, Zé Burraldo abriu a tampa do caixão, botou a cabeça para fora e sapecou:

- No tempo que eu era vivo, o melhor caminho era pelo atalho!

Ao ver o defunto falar, o padre e o povo largaram o caixão no chão, gritaram Cruz credo! - e saíram correndo. Dizem que continuam correndo até hoje. Sem ninguém que o enterrasse, Zé Burraldo ainda ficou ali deitado um bom tempo. No fim, cansado de ficar no caixão sem fazer nada, desistiu de estar morto e voltou para casa. Continuou tocando a vida pra frente e ainda durou muitos e muitos anos.

Fragmento do texto "Façanhas do Zé Burraldo". AZEVEDO, R. História de bobos, bocós, burraldos e paspalhões. 1.ed. São Paulo: Ática, 2009. 
Anexo 8 - Etapa 1: Do acervo popular à adaptação (pág. 26).

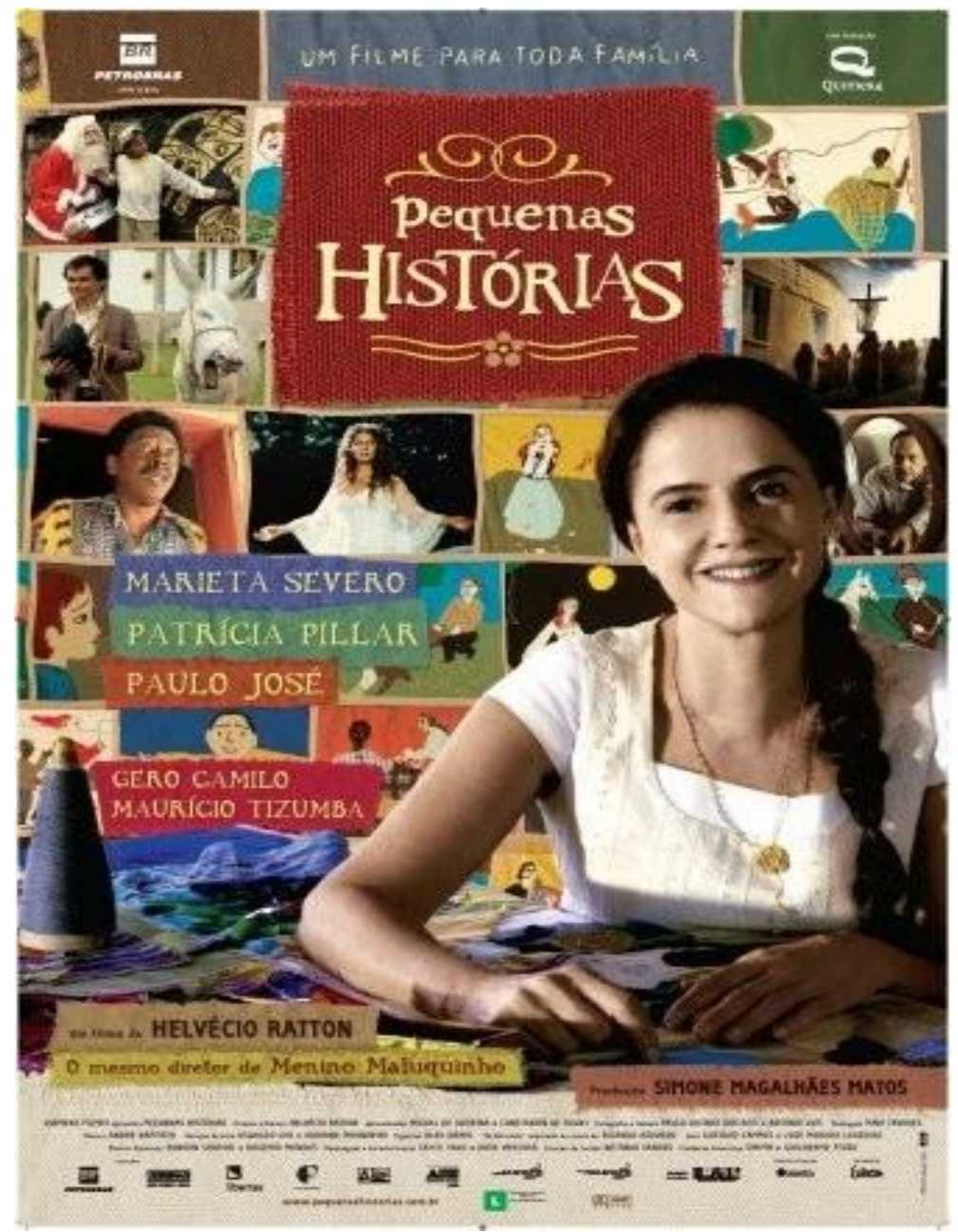

Disponível em http://www.adorocinema.com/filmes/filme-202261/ Acesso em nov. 2020.

Filme disponível em http://tvines.org.br/?p=15991 Acesso em nov.2020. 
Anexo 9 - Etapa 1: Do acervo popular à adaptação (págs. 27 e 33).

Filme: Pequenas Histórias (2007) do diretor Helvécio Ratto, disponível em: http://tvines.org.br/?p=15991 
Anexo 10 - Etapa 1: Do acervo popular à adaptação (págs. 27 e 28).

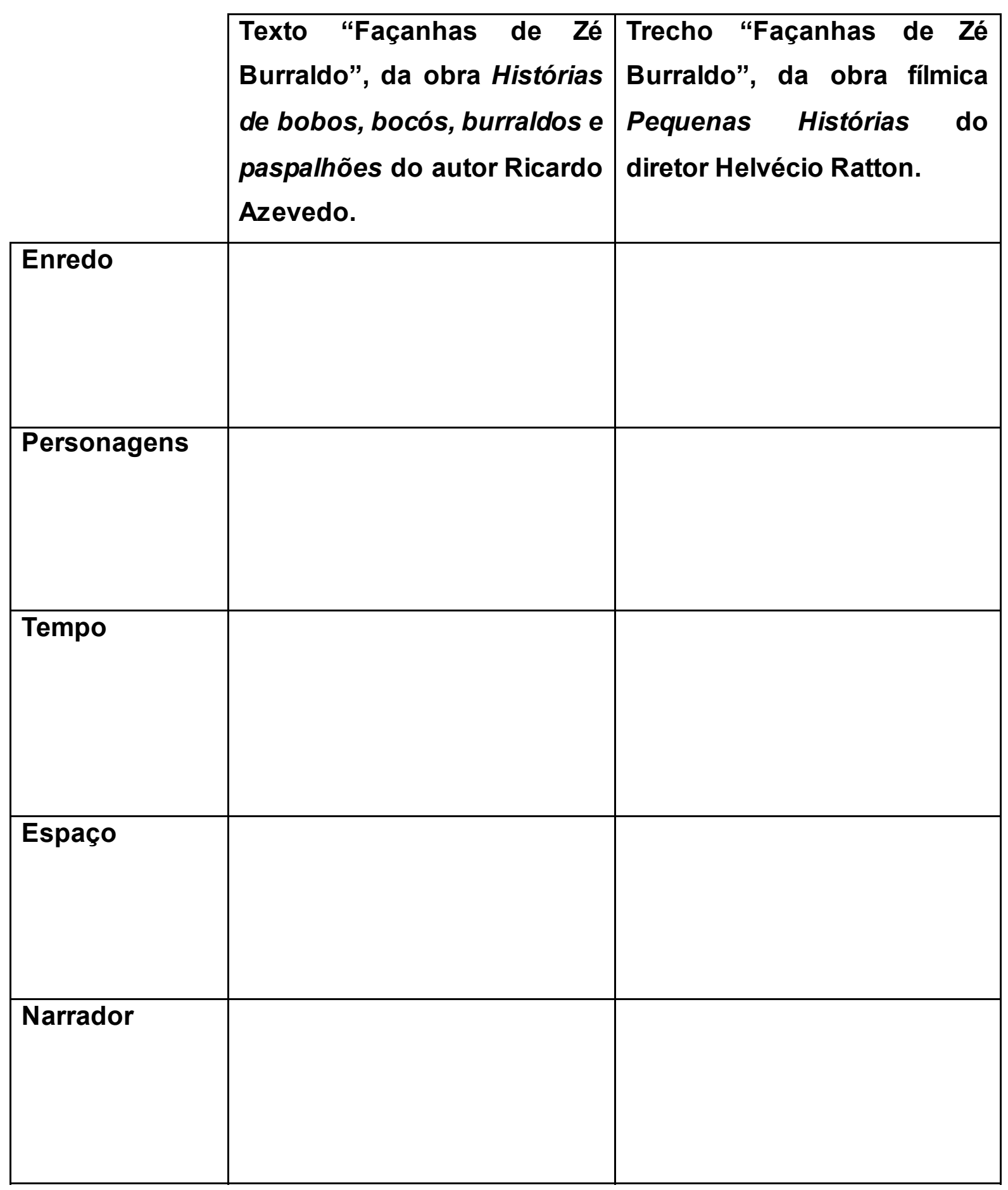


Anexo 11 - Etapa 2: Do "causo" à adaptação (págs. 30 e 32).

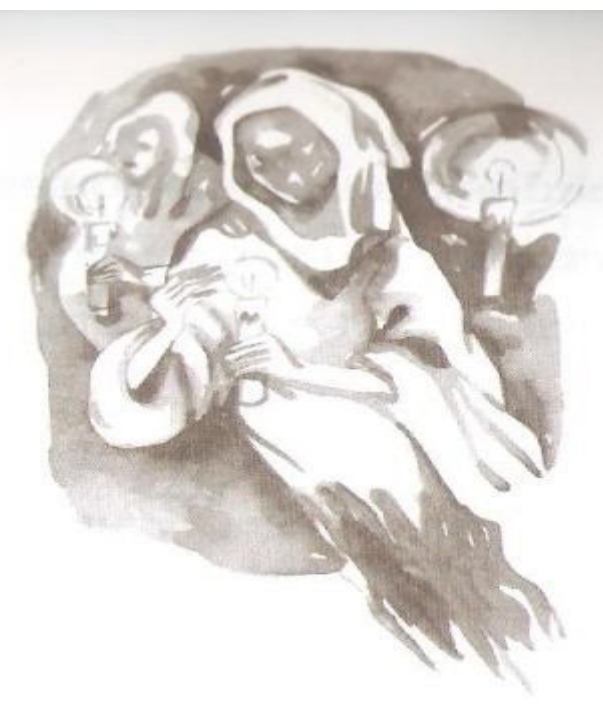

PROCISSÃO DAS ALMAS

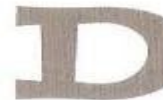

evia contar sem rodeios. Gosto mais quando sou objetivo: exponho, estabeleço o conflito e encerro o desenlace. Entrar e acabar logo com o assunto é um desencargo. No entanto, nesta história, minha memória não permite. Exige-me que revele como tomei conhecimento do enredo. Coisa tola. Dispensável. Entretanto, para mim, que vivi a situação, os detalhes possuem certa importância.

Quando menino, eu aguardava com ansiedade a passagem de um caixeiro-viajante de tecidos para fazer colchões. Mal ele chegava, eu dava um jeito de ir me aproximando: 


\section{Anexo 11 - Cont.,}

- Seu Hugo!

- O que foi? - ele parava o que fazia e me encarava como se eu fosse gente grande.

- Como é mesmo a história do seu primo?

- Que história? - ele fingia forçar a lembrança, como se houvesse me contado outras.

- Da procissão das almas.

- Já lhe contei mais de mil vezes.

- Esqueci uma parte - eu mentia, para ouvir mais uma vez. Então, ele começava dizendo que um de seus primos sempre fora muito curioso. Desde menino, tudo queria saber, ver, tocar e ouvir. Desmontava o mundo para conhecer seu funcionamento. Observava a natureza e adorava ouvir os adultos conversarem. Mesmo que para isso tivesse de se esconder atrás de algum móvel. Precisou levar muita bronca do pai e da mãe para aprender a não olhar pelo buraco da fechadura. Acabou se acostumando a ser chamado de xereta.

Assim, aos onze anos, ouviu os adultos falando sobre a procissão das almas. Fez perguntas. Desconversaram. Achou que lhe negavam resposta para não assustá-lo. Consultou os amigos para saber se conheciam a história. Nunca ouviram falar a respeito nem queriam. Foi atrás de informações. Indagou de um lado, investigou do outro e acabou descobrindo muita coisa.

Tomou conhecimento de que a tal procissão acontecia faltando pouco para meia-noite do Dia de 


\section{Anexo 11 - Cont.,}

a movimentação. A procissão saiu do campo-santo, ganhou a rua e foi se aproximando da casa dele. Não havia cantoria nem reza. Achou bonito ver tantas velas acesas nas mãos dos muitos acompanhantes, enfileirados em paralelas. Com o intento de ver os rostos dos integrantes, arriscou abrir uma folha da janela. Por mais que fixasse os olhos, não conseguia enxergar. Só via uma mancha negra no lugar dos rostos. Mesmo assim, não ficou com medo. Só meio enjoado com o cheiro das velas queimando.

Quando a procissão passava em frente da sua casa, um dos acompanhantes saiu do cortejo e se dirigiu a ele, que entrou em pânico. Sentiu vontade de gritar por socorro. Não conseguiu. Quis fugir dali. Estava estático: pés colados no chão e um frio correndo pela espinha. Tentou fechar a janela. As mãos não the obedeciam. A alma continuou vindo em sua direção. Ao se aproximar, ofereceu-lhe uma vela acesa. Ele não queria pegar, mas seu braço se alongou e sua mão aceitou. Só aí viu que os integrantes da procissão não possuíam rosto. Tentou jogar a vela, mas sua mão a segurava firmemente. Seus dedos não abriam para soltá-la ao chão. Enquanto isso, a procissão seguia em frente. Voltava para o cemitério, sob o badalar do sino da igreja da necrópole.

Quando o sino da igreja matriz bateu as badaladas da meia-noite, como que por encanto, tudo se desfez. O cemitério voltou a seu silêncio e sua escuridão. 
- E daí, seu Hugo? - eu perguntava, porque ele sempre parava nessa passagem, esperando por minha pergunta.

- Meu primo olhou para a vela - e estancava fazendo suspense. Só depois dessa pausa, revelava:-Ela havia apagado e se transformado num osso da canela de um defunto, na sua mão.

- E aí, seu Hugo?

- Ficou desesperado como um louco. Chamou a mãe e contou tudo. Toda a família entrou em desespero. A madrugada foi de horror. A notícia se esparramou pela cidade inteira, antes do amanhecer. Uma vizinha piorou a situação, dizendo que quem tocasse naquele osso morreria. Diante dessa afirmação, ele já se considerava defunto. Os parentes e os amigos choravam. Só minha avó teve cabeça para prometer que, se meu primo não morresse, ela rezaria todas as noites para as almas, até o último dia da sua vida. E, assim, ela se comprometeu e cumpriu.

Este é o fim da história. No entanto, a sensatez exige que eu agradeça a seu Hugo, por, um dia, vendo-me no sufoco com a minha tarefa escolar, ele ter parado de emitir uma nota fiscal e me ensinado a escrever a palavra "baleia". 
Anexo 12 - Etapa 2: Do “causo" à adaptação (págs. 33 e 34).

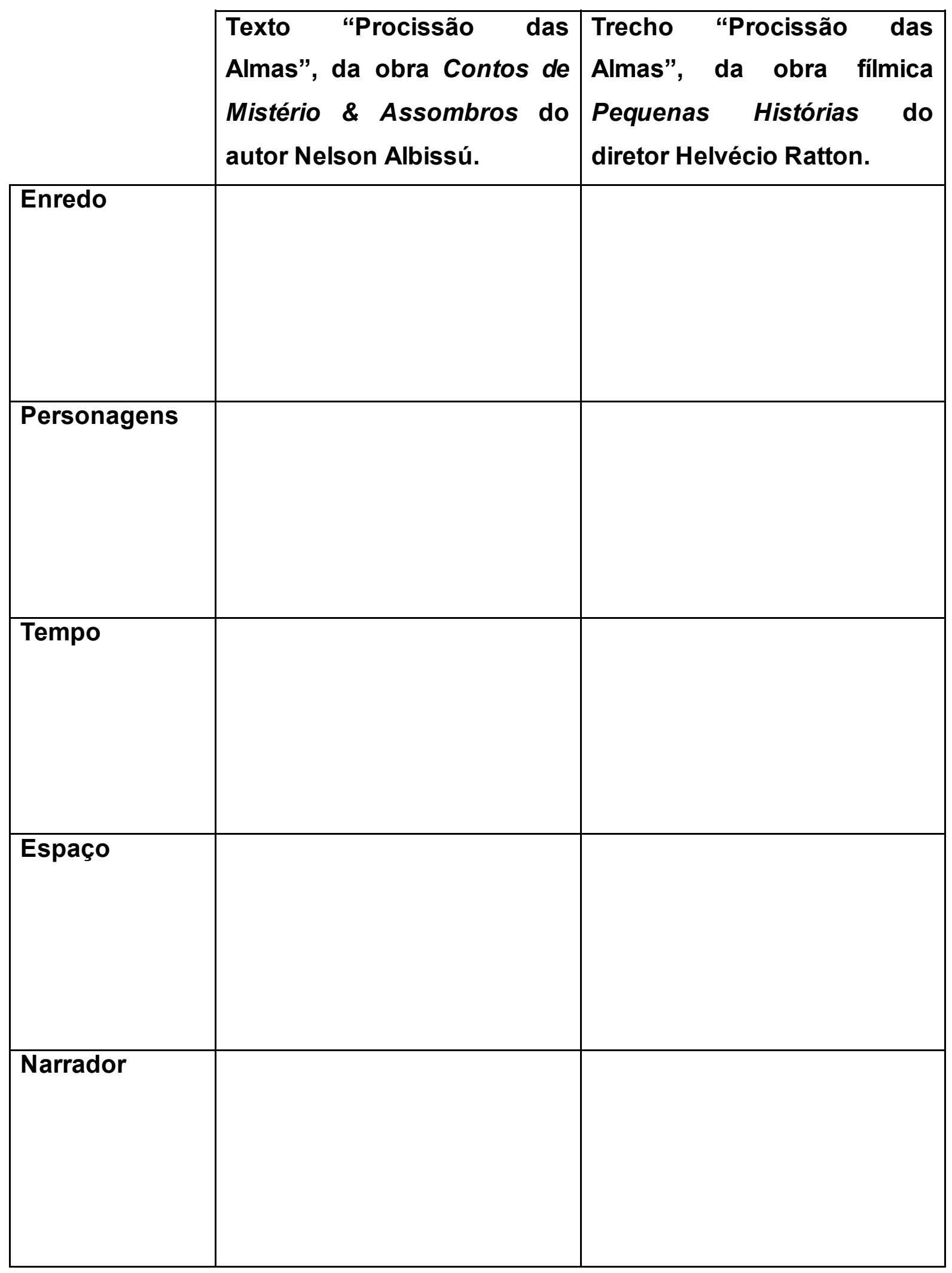


Anexo 13 - Etapa 3: Uma adaptação filmica (pág. 35).

Filme o "Homem Nu" editado. Disponível em

https://drive.google.com/drive/folders/18Li8JY2AamvctMjo3VKBf2Pn4iyVpYb0?usp=sh aring 
Anexo 14 - Etapa 3: Uma adaptação filmica (págs. 35 e 40).

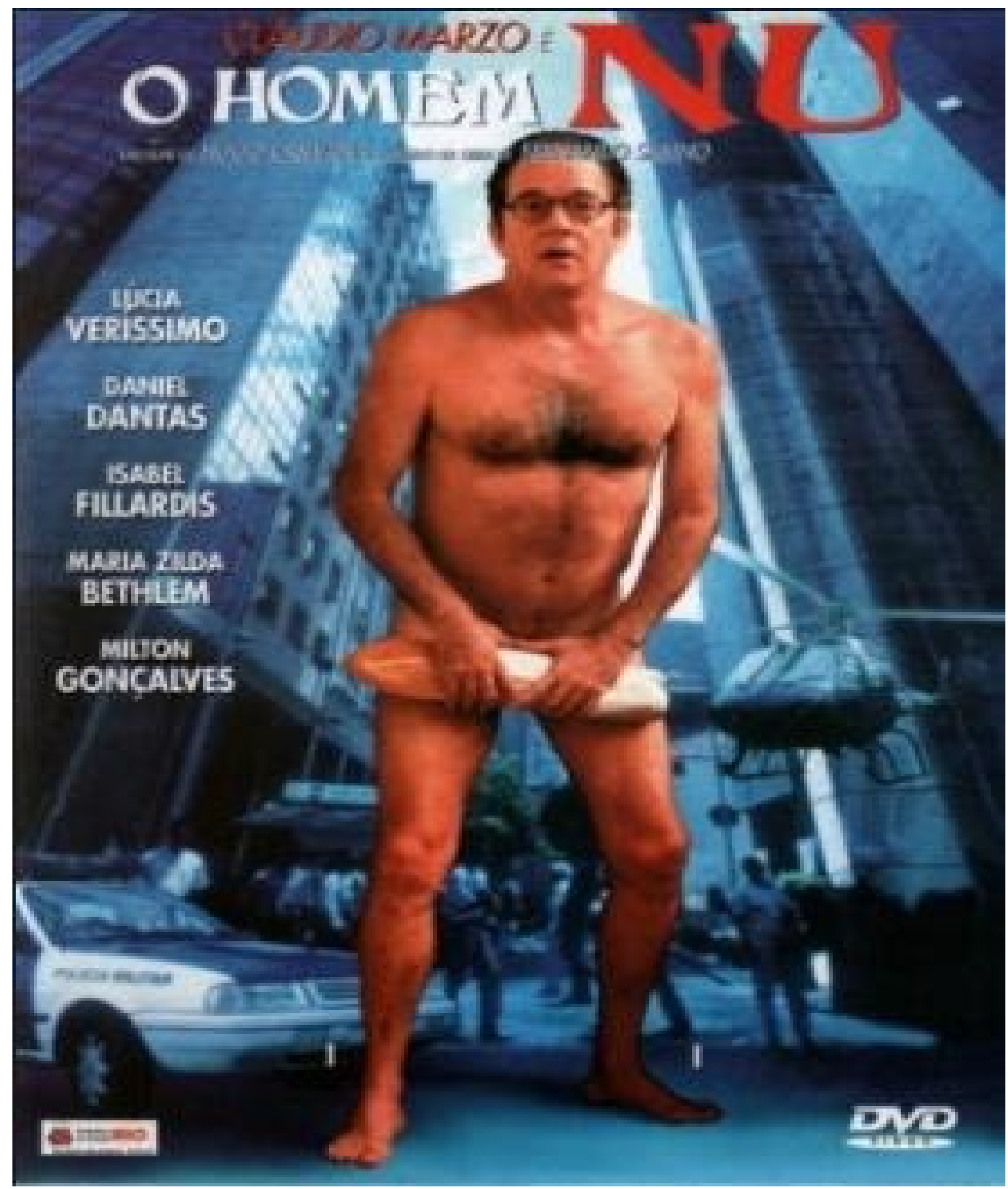

Disponível em http://w w w .adorocinema.com/filmes/filme-18089/ Acesso em jan. 2021. 
Anexo 15 - Etapa 3: Uma adaptação filmica (pág. 36).

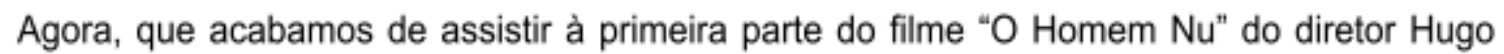
Carvana, questiono a vocês:

1- Qual a impressão que vocês tiveram dessa primeira parte que acabamos de assistir? Por quê?

2- Geralmente, um filme, em seu início, apresenta alguns elementos estruturadores, que visam situar o espectador em relação à trama que se desenrolará durante a obra cinematográfica. Esses elementos, geralmente, servem para nos ambientar quanto aos fatos introdutórios, os personagens, o tempo e o espaço em que a história irá se desenvolver. A partir dessa perspectiva, respondam:

a) A trama inicial do filme se desenrola em qual cenário geográfico? Como você identificou isso no filme?

b) Na trama, há muitos ou poucos personagens? Você poderia identificar alguns deles?

c) Para vocês, quem é o personagem central da trama? Por quê?

d) Como é caracterizado socialmente (profissão, onde trabalha, estado civil) o personagem central da trama?

e) Que fato impede o personagem central de não embarcar para São Paulo?

f) Em razão da situação que não permite o embarque do personagem central e de alguns conhecidos que ele encontrou no aeroporto de Santos Dumont, para onde eles vão?

g) Para vocês, esse lugar para onde eles vão, será crucial para a história do personagem central? Por quê?

3- $\mathrm{Na}$ última cena dessa primeira parte, o que vocês acham que irá acontecer com o personagem principal? 
Anexo 16 - Etapa 3: Uma adaptação filmica (pág. 37).

Agora que acabamos de assistir a segunda etapa do filme, para iniciarmos o debate sobre essa parte, pergunto a vocês:

1- As hipóteses que vocês levantaram na última aula, a partir da pergunta de número 3 (Na última cena dessa primeira parte, o que vocês acham que irá acontecer com o personagem principal?), se confirmaram ou nấo? Por quê?

2- Observe a cena abaixo e responda as questões:

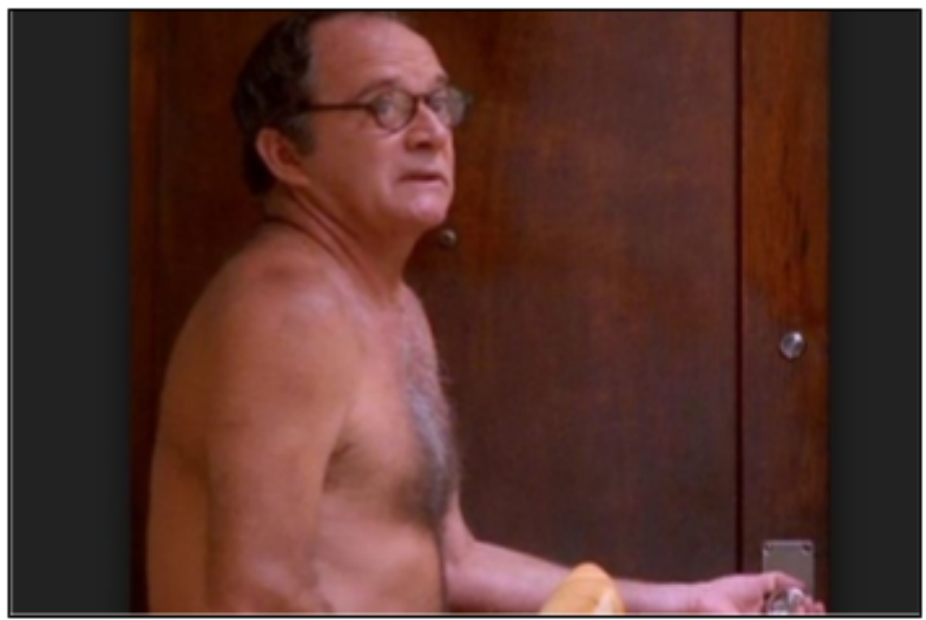

https:/lentretenimento, $r 7$. com/famosos-e-tvifotosirelembre-a-carreira-do-ator-claudio-marzo-06102019\#il/foto/1 Acesso em 13.jan.2021.

a) Onde a cena aconteceu?

b) Qual a importância dessa cena para a história?

3- Qual é o período de tempo decorrido durante o trecho do filme assistido?

4- Quais são os espaços que o personagem central percorre durante o trecho mostrado?

5- Com quais outros personagens o personagem Proença interage?

6- Na última cena dessa segunda parte, o que vocês acham que irá acontecer? Quais hipóteses podemos elaborar para o que virá a ocorrer posteriormente? 
Anexo 17 - Etapa 3: Uma adaptação filmica (pág. 38).

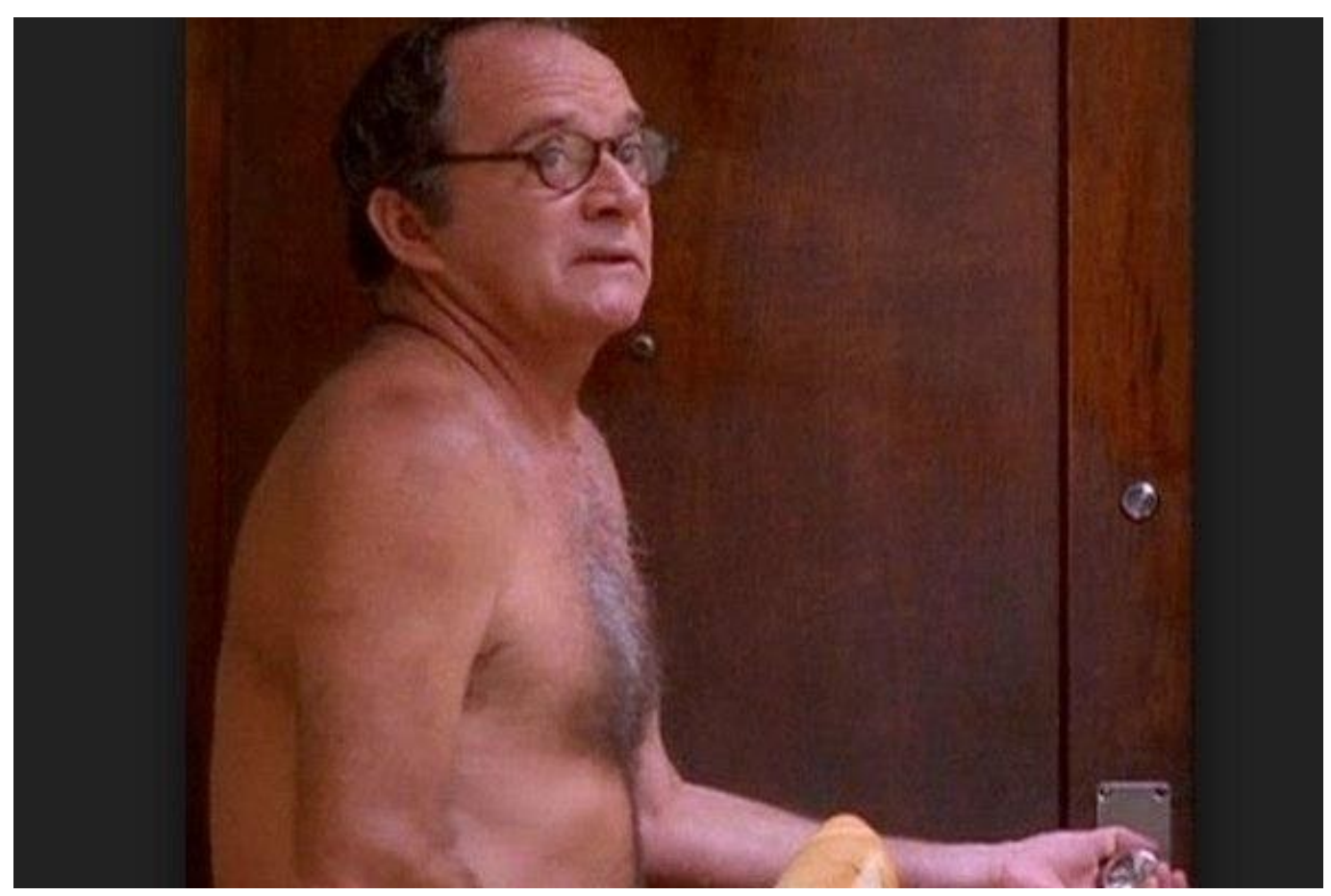

https://entretenimento.r7.com/famosos-e-tv/fotos/relembre-a-carreira-do-ator-claudio-marzo-06102019\#!/foto/1 Acesso em 13.jan.2021. 
Anexo 18 - Etapa 3: Uma adaptação filmica (pág. 39).

Agora que acabamos de assistir a última parte do filme, para iniciarmos o debate sobre essa parte, pergunto a vocês:

1- As hipóteses que vocês levantaram na última aula, a partir da pergunta de número 6 (Na última cena dessa segunda parte, o que vocês acham que irá acontecer? Quais hipóteses podemos elaborar para o que virá ocorrer posteriormente?), se confirmaram ou não? Por quê?

2- Ao chegar ao apartamento onde mora, o que acontece?

3- Em relação ao tempo que se desenrola durante toda a ação da obra fílmica, podemos dizer que ele foi cronologicamente linear? Por quê?

4- Durante a ação fílmica, há um personagem que acompanha toda saga de Silvio Proença. Quem é esse personagem? Qual a importância dele para o personagem central?

5- Em relação ao desfecho do filme, era o que vocês esperavam? Foi impactante? Justifique. 
Anexo 19 - Etapa 4: Da adaptação ao texto original (pág. 40).

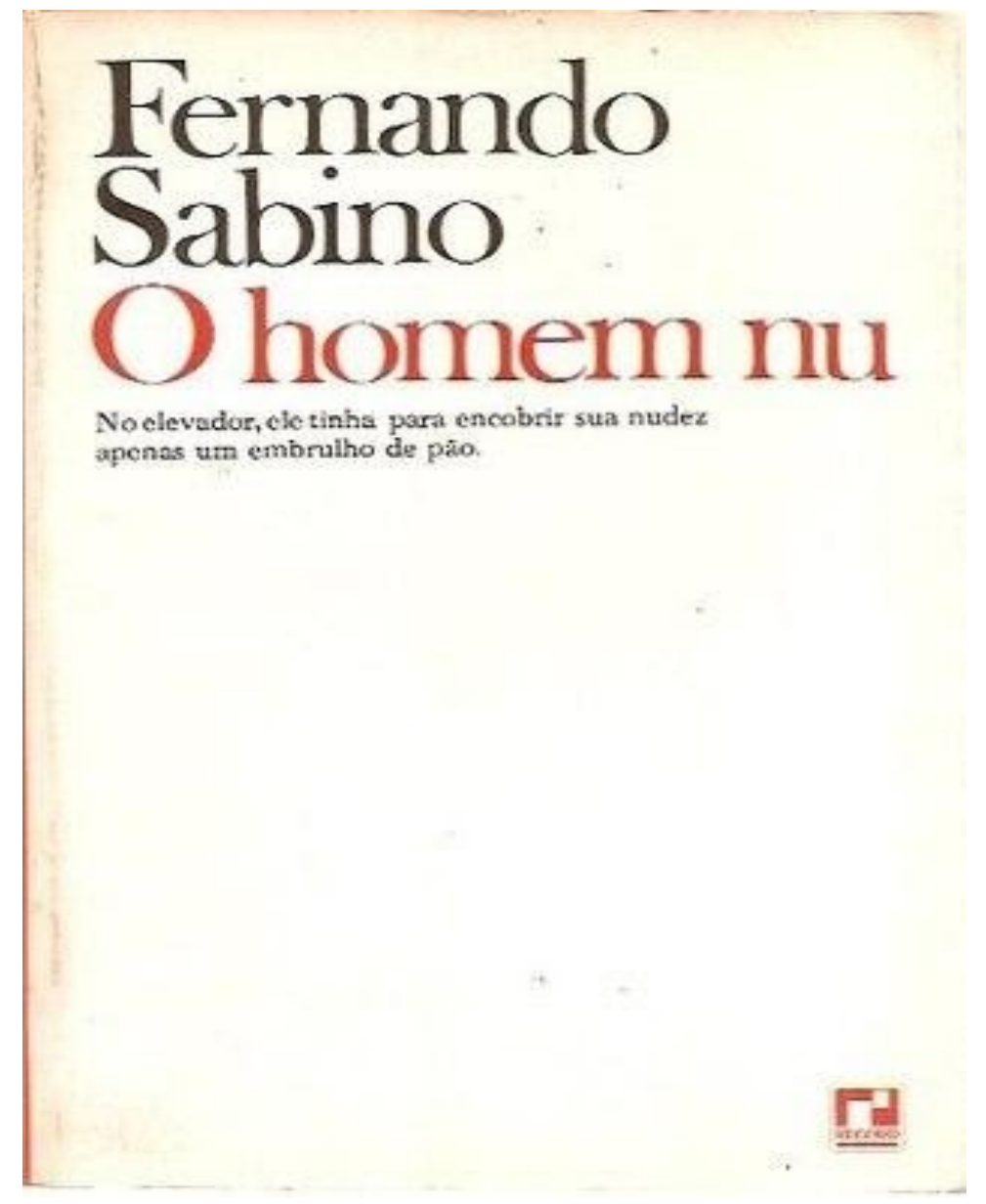

Disponível em https://w w w.goodreads.com/book/show /91176.0 Homem Nu Acesso em jan. 2021. 
Anexo 20 - Etapa 4: Da adaptação ao texto original (pág. 41).

Adaptação é um modo de recontar uma determinada história já bastante conhecida pelo público através do mesmo suporte ou através de outras mídias. Pode haver modificações significativas em relação à obra original, o que faz da adaptação uma obra nova com características próprias. Essas modificações, que diferenciam a obra original da adaptada, evidenciam-se desde o ponto de vista até as escolhas de quem a produz. Essas variações podem aparecer nos personagens, na descrição visual dos cenários, nos espaços em que ocorre a história, na duração, em quem conta a história e até mesmo no enredo que motiva a ação (conceito elaborado a partir da obra Teoria da adaptação da autora Linda Hutcheon, 2013). 
Anexo 21 - Etapa 4: Da adaptação ao texto original (pág. 41).

O HOMEM NU

AO ACORDAR, 'disse para a mulher:

- Escuta, minha filha: hoje é dia de pagar a prestação da televisão, vem aí o sujeito com a conta, na certa. Mas acontece que ontem eu não trouxe dinheiro da cidade, estou a nenhum. mulher.

- Explique isso ao homem - ponderou a

- Não gosto dessas coisas. Dá um ar de vigarice, gosto de cumprir rigorosamente as minhas obrigações. Escuta: quando ele vier a gente fica quieto aqui dentro, não faz barulho, para ele pensar que não tem ninguém. Deixa ele bater até cansar - amanhã eu pago.

Pouco depois, tendo despido o pijama, dirigiuse as banheiro para tomar um banho, mas a mulher já se trancara lá dentro. Enquanto esperava, resolveu fazer um café. Pós a água a ferver e abriu a porta de serviço para apanhar o pão. Como estivesse completarnente nu, olhou com cautela para um lado e para outro antes de arriscar-se a dar dois passos até o embrulhinho deixado pelo padeiro sobre o mármore 
do parapeito. Ainda era muito cedo, não poderia aperecer ninguém. Mal seus dedos, porém, tocavam o pão, a porta atrás de si fechou-se com estrondo, impulsionada pelo vento.

Aterrorizado, precipitou-se até a campainha $e$ depois de tocá-la, ficou à espera, olhando ansiosamente ao redor. Ouviu lá dentro o ruído da água do chuveiro interromper-se de súbito, mas ninguém vein abrir. Na certa a mulher pensava que já era o sujeito da televisão. Bateu com o nó dos dedos:

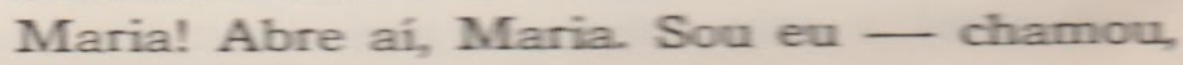
em voz baixa.

Quanto mais batia, mais silêncio fazia lá dentra.

Enquanto isso, ouvia lá embaixo a porta do elevador fechar-se, viu o ponteiro subir lentamente os andares. . . Desta vez, era o homem da televisão!

Não era. Refugiado no lanço de escada entre os andares, esperou que o elevador passasse, e voltou para a porta de seu apartamento, sempre a segurar nas mãos nervosas o embrulho de pão:

- Maria, por favor! Sou eu!

Desta vez não teve tempo de insistir: ouviu passos na escada, lentos, regulares, vindos lá de baixo... Tomado de pânico, olhou ao redor, fazendo uma pirueta, e assim despido, embrulho na mão, parecia executar um ballet grotesco e mal ensaiado. Os passos na escada se aproximavam, e ele sem onde se esconder. Correu para o elevador, apertou o botão. Foi o tempo de abrir a porta e entrar, e a empregada passava, vagarosa, encetando a subida de mais um lanço de escada. Ele respirou aliviado, enxugando o suor da testa com o embrulho do pão. Mas eis que a porta interna do elevador se fecha e ele começa a descer.

66 
bressaltado.

Ah, isso é que näo! _ fez o homem nu, so-

E agora? Alguém lá embaixo abriria a porta do elevador e daria com ele ali, em pêlo, podia mesmo ser algum vizinho conhecido... Percebeu, desorientado, que estava sendo levado cada vez para mais longe de seu apartamento, começava a viver um verdadeiro pesadelo de Kafka, instaurava-se naquele momento o mais autêntico e desvairado Regime do Terror!

Isso é que não - repetiu, furioso. :

Agarrou-se à porta do elevador e abriu-a com força entre os andares, obrigando-o a parar. Respirou fundo, fechando es olhos, para ter a momentânea ilusão de que sonhava. Depois experimentou apertar o botão do seu andar. Lá embaixo continuavam a chamar o elevador. Antes de mais nada: "Emergência: parar". Muito bem. E agora? Iria subir ou descer? Com cautela desligou a parada de emergência, largou a porta, enquanto insistia em fazer o elevador subir. O elevador subiu.

- Maria! Abre esta porta! - gritava, desta vez esmurrando a porta, já sem nenhuma cautela. Ouviu que outra porta se abria atrás de si. Voltou-se, acuado, apoiando o traseiro no batente e tentando inutilmente cobrir-se com o embrulho de pão. Era a velha do apartamento vizinho:

- Bom dia, minha senhora - disse ele, confuso. - Imagine que eu...

A velha, estarrecida, atirou os braços para cima, soltou um grito:

- Valha-me Deus! O padeiro está nu! trulha:

$\mathrm{E}$ correu ao telefone para chamar a radiopa- 
- Tem um homem pelado aqui na porta!

Outros vizinhos, ouvindo a gritaria, vieram ver o que se passava:

- É um tarado!

- Olha, que horror!

- Não olha não! Já pra dentro, minha filha!

Maria, a esposa do infeliz, abriu finalmente a porta para ver o que era. Ele entrou como um foguete e vestiu-se precipitadamente, sem nem se lembrar do banho. Poucos minutos depois, restabelecida a calma lá fora, bateram na porta.

- Deve ser a polícia _ disse ele, ainda ofegante, indo abrir.

Não era: era o cobrador da televisão. 
Anexo 22 - Etapa 4: Da adaptação ao texto original (pág. 42).

\section{Gênero Textual Conto}

Conceito: Narrativa curta que apresenta apenas um conflito ou ação, que se desenvolve em determinado espaço, comumente restrito a poucos ou a um único ambiente, em curta duração de tempo, limitado por dias ou horas, contendo um número bem reduzido de personagens e que é contada, ou seja, narrada por alguém, que pode ou não participar da história (conceito elaborado a partir da obra A criação literária - introdução à problemática da literatura do autor Massaud Moisés, 1970). 
Anexo 23 - Etapa 5: Atividade avaliativa (pág. 47).

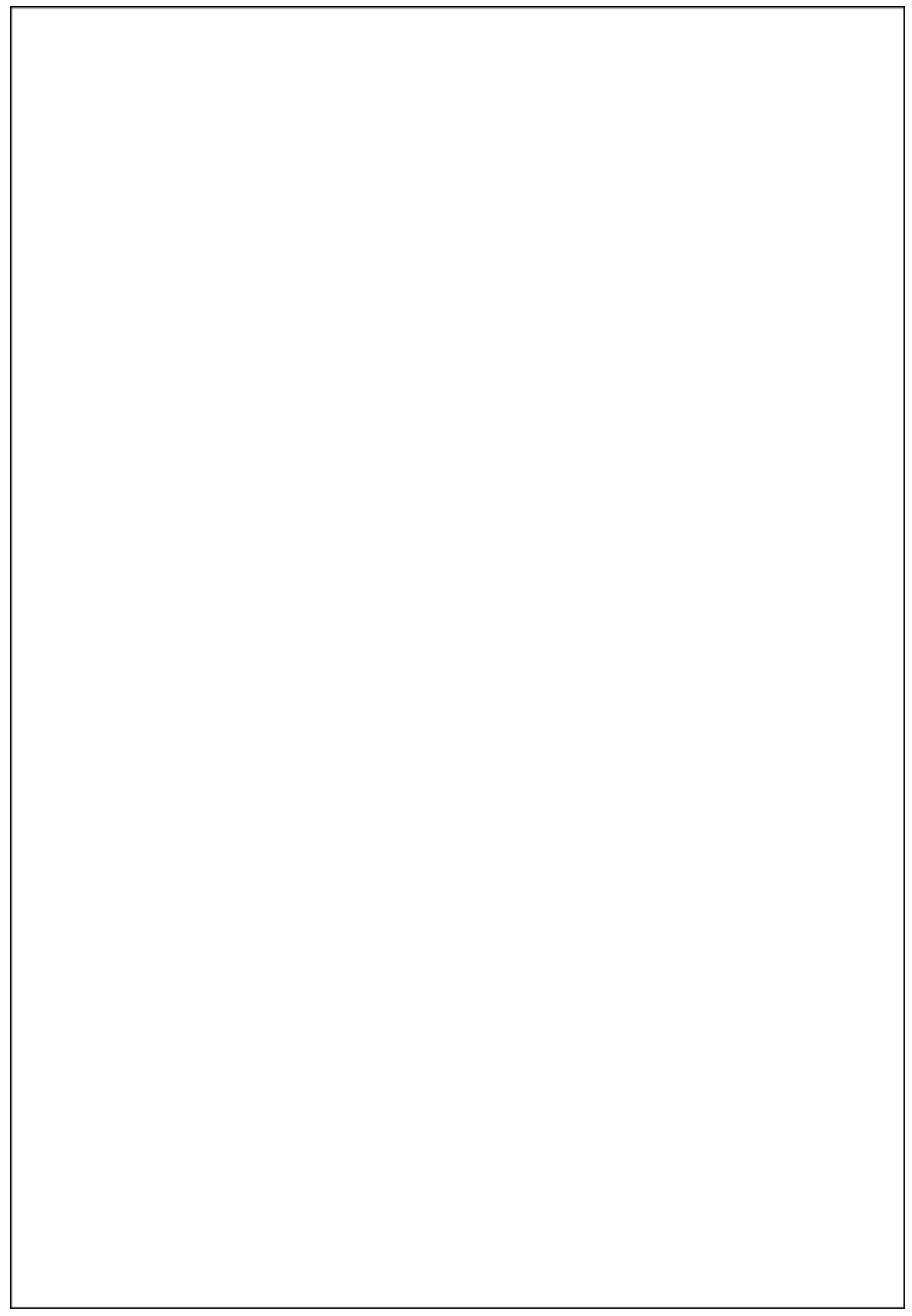


Anexo 24 - Etapa 5: Atividade avaliativa (pág. 47).

Dupla: 


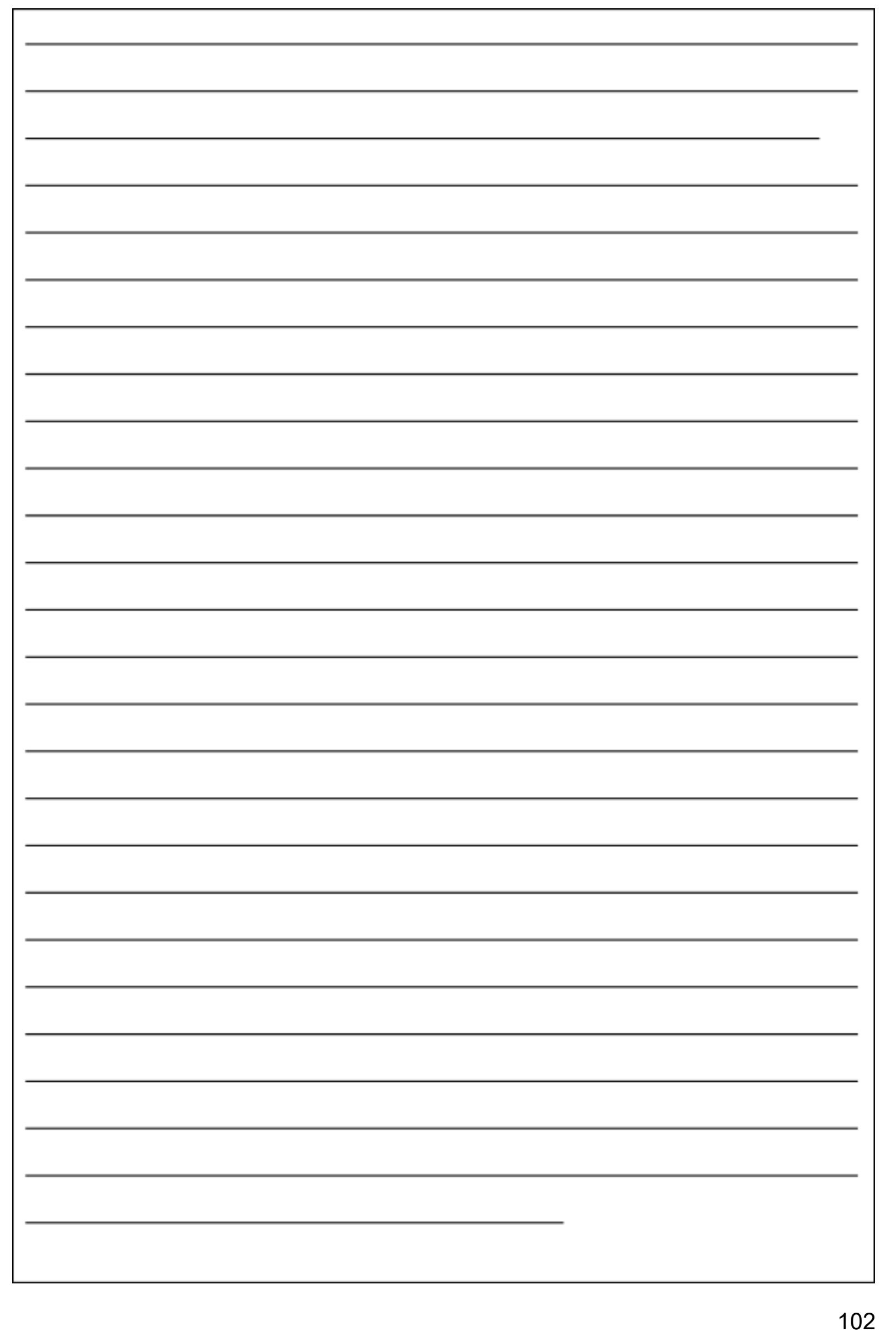


Anexo 25 - Etapa 5: Atividade avaliativa (pág. 50).

\section{FOLHA DE VOTAÇÃO}

TÍTULO DO CONTO

JUSTIFICATIVA, CONFORME CONTEÚDO APRENDIDO DURANTE AS AULAS. 


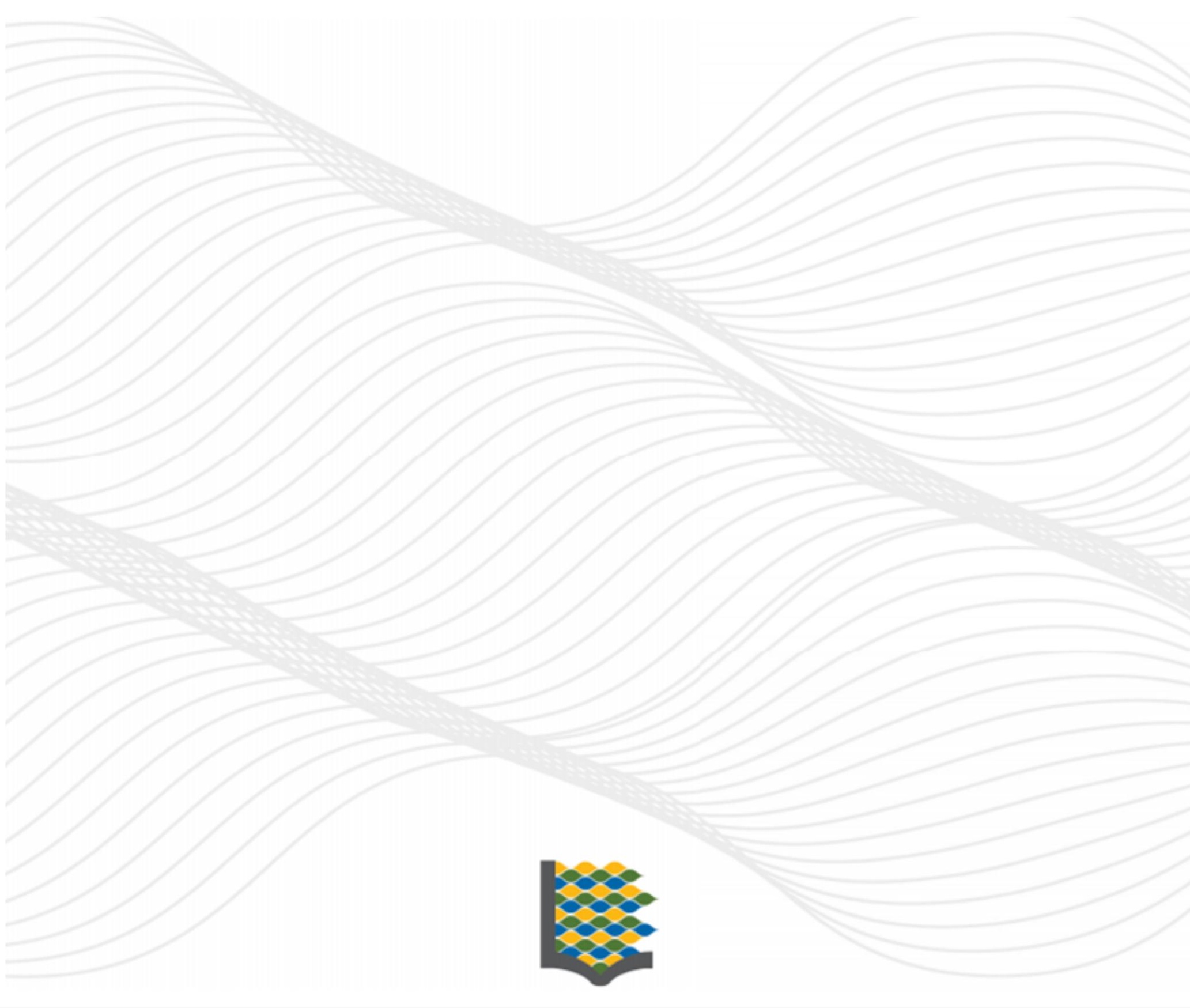

